UDC $004.9+004.451+911.3$

Sergiy Vasylovych Kostrikov,

Doctor of Sciences (Geography), Professor, Department of Human Geography and Regional Studies, School of Geology, Geography, Recreation and Tourism, V. N. Karazin Kharkiv National University, 4 Svobody Sq., Kharkiv, 61022, Ukraine;

e-mail: sergiy.kostrikov@gmail.com, https://orcid.org/0000-0002-4236-8474;

Dmytro Yevgenovych Bubnov,

Scientist and Senior Programmer, EOS Data Analitics Ukraine, LLC,

31 Alchevskyh St., Kharkiv, 61002, Ukraine,

e-mail: dmitriy.bubnov@eosda.com, https://orcid.org/0000-0002-2851-8659;

Rostyslav Anatoliyovych Pudlo,

R\&D Team Leader, EOS Data Analitics Ukraine, LLC,

e-mail: rostyslav.pudlo@eosda.com, https://orcid.org/0000-0002-3018-2074

\title{
URBAN ENVIRONMENT 3D STUDIES BY AUTOMATED FEATURE EXTRACTION FROM LiDAR POINT CLOUDS
}

С. В. Костріков, Д. Є. БУбнов, Р. А. Пудло. ДОСЛІДЖЕННЯ ТРИВИМІРНОГО ПРОСТОРУ МІСЬКОГО СЕРЕДОВИЩА ЧЕРЕЗ АВТОМАТИЗОВАНЕ ВИОКРЕМЛЕННЯ ОБ'СКТІВ ІЗ ХМАР ЛІДАРНИХ ТОЧОК. Стаття розгЛЯає багатофункиіональну методологію і практичну методику геообробки даних дистаниійного лазерного (лідарного) зондування міського середовища у иілях його подальшого модельного відтворення та дослідження. Окремо підкреслюються як сучасні запити на залучення новітніх технологій до ичих досліджень, так $і$ виклики, щчо подібне залучення супроводжують. Докладний літературний огляд надає принципове розуміння головних положень автоматизованого виокремлення урбанізірованих об 'єктів (АВУО) як головної складової геообробки хмар лідарних точок. Описуються окремі кроки АВУО як-то «визначення», «класифікація», «сегментація» та «реконструкиія».

Представлене авторське програмне забезпечення (ПЗ) у вигляді веб-ГІС-застосування, призначеного для інтеграчії різноманітних лідарних даних із наступною візуалізацією проміжних та кінцевих результатів їх обробки. Коротко розглянуті архітектурна схема иъього веб-застосування як розподіленої інформаційної системи та його головні функиіональності: Виокремлення будівель; Виокремлення будівель у сільській місиевості; Визначення змін у архітектурній морфології міста; Генерачія топографічної поверхні. Детально розглядаються дві авторські модифікаиії альтернативних підходів у рамках АВУО - високополігональне та низькополігональне моделювання зі створенням «великовагових» та «низьковагових» моделей, відповідно.

Зокрема, пропонується низька оригінальних рімень за допомогою побудови діаграми Вороного на етапі реконструкиї моделей будівель. Представлено веб-портал - геопортал авторського ПЗ, який надає доступ як до проектів із відтвореним міським середовищем по різних країнах, так і до відповідних інструментів обробки первинних лідарних даних користувача. У якості практичних прикладів називається декілька можливих сценаріїв користувача (иsе-саsеs - англ.) щэодо реалізації функиіональності геопорталу.

Ключові слова: лідар, лідарні дані, міське середовище, АВУО, моделі будівель, веб-ГІС-застосування, геопортал.

С. В. Костриков, Д. Е. БУбнов, Р. А. Пудло. ИССЛЕДОВАНИЯ ТРЕХМЕРНОГО ПРОСТРАНСТВА ГОРОДСКОЙ СРЕДЫ ПОСРЕДСТВОМ АВТОМАТИЗИРОВАННОГО ВЫДЕЛЕНИЯ ОБЪЕКТОВ ИЗ ОБЛАКОВ ЛИДАРНЫХ ТОЧЕК. Статья рассматривает многофункииональную методологию и практическую методику геообработки данных дистанционного лазерного (лидарного) зондирования городской среды в ичелях ее дальнейшего модельного представления и исследования. Отдельно подчеркиваются как современные запросы на использование новейших технологий в указанных исследованиях, так и вызовы, которые будут сопровождать это использование. Пространный литературный обзор обеспечивает принципильное понимание основных положений автоматизированного выделения урбанизированных объектов (АВУО) как основной составной геообработки облаков лидарных точек. Описываются отдельные шаги АВУО как-то «определение», «классификация», «сегментация» и «реконструкиия».

Представлено авторское программное обеспечение (ПО) в виде веб-ГИС-приложения, предназначенного для интеграиии разнообразных лидарных данных с последующей визуализачией промежуточных и окончательных результатов их обработки. Вкратие рассмотрены архитектурная схема этого веб-приложения как распределенной информационной системы и его основные функииональности: Извлечение зданий; Извлечение зданий в сельской местности; Определение изменений 8 архитектурной морфології города; Генераиия топографической поверхности. Детально рассматриваются две авторские модификации альтернативных подходов в рамках АВУО - высокополигональное и низкополигональное моделирование с созданием «тяжеловесных» и «легковесных» моделей, соответственно. В частности, предлагается ряд оригинальных решений с помощью построения диаграммы Вороного на этапе реконструкиии моделей зданий. Представлен веб-портал - геопортал авторского ПО, который обеспечивает доступ как к проектам со смоделированной городской средой по разным странам, так и к соответствующим инструментам обработки первичных лидарных данных пользователя. В качестве практических примеров возможных сиенариев пользователя для реализации функциональности геопортала.

Ключевые слова: лидар, лидарные данные, городская среда, АВУО, модели зданий, веб-ГИС-приложение, геопортал.

Research problem introduction. The continuing significant growth of urban population all over the world and, first of all, in Africa, Asia and Latin America forces scientists to seek new advances in
Urban Studies, which primarily means to involve innovative approaches and techniques in the Information Technology and Remote Sensing domains. Thus, it seems evident that remote sensing data pro- 
cessing and modeling tools, which may assist in urban studies, can hardly be overvalued. Contemporary global urban mapping, using Earth Observation systems is the only possible approach that guarantees getting rid of the shortage of reliable spatial information of urban areas throughout the Earth $[1,2]$.

We have already emphasized recently that the key issues of the contemporary urban development had caused a number of challengers that would require the innovative technological introductions in the Urban Studies domain. These challengers and the innovations can be summarized like follows [3, 4], and they are outlined in the first visual of this text, as those ones that can be resolved and provided with indispensable Urban Remote Sensing (URS) tools (Fig. 1): 1) with prompt development and drastic changes in urbanization processes, the explorations of city areas have to become the studies of urban systems, which are also becoming more and more sophisticated; 2) the number of cities increased and the urban areas are being enlarged extremely promptly, especially in developing countries; 3) the regions with extensive urban constructions not only become more and more numerous, but also they grow fast in different countries; 4) a necessity for terrain models of high accuracy for urban planning and other related sophisticated spatial data processing become quite understandable and can be applicable for different subject domains beyond straightforward urban planning and municipal management; 5) a necessity for effective automated buildings survey to determine quantitative and qualitative characteristics of architectural changes over time is accepted as a mandatory component of city alterations monitoring; 6) high accuracy environmental surveys over the key cities in the area-of-interest (AOI) with extensive remote sensing data analysis should be regularly provided. Therefore, a geographer-urbanist seeks for both a reliable research approach, and the mentioned above advanced tools to understand the nature and spatial phenomena of the urbanization processes in a given area. The relevant theory and its derivative applied solutions meet the necessity for more efficient urban mapping, city understanding, and municipal management. All three mentioned domains may be combined in one innovative development - 3D City Cadaster, that is intended to resolve those complex property and infrastructural situations, in which a traditional 2D digital cadaster is rather limited [5].

A Geographical Information System (GIS) is another key definition in our text. Nowadays a GIS is broadly employed every day by various specialists for both routine, and complicated procedures with spatial information formats: digital elevation models and digital surface models; raster datasets - satellite / airborne images and derivative results of their processing; vector datasets - roads, other infrastructural networks rivers, contours; raster map data - aerial photos, satellite images; 3D objects - buildings, geobodies; CAD (Computer Aided Design) data - surfaces and subsurface, volumetric geometric figures, etc.; LiDAR (Light Detection and Ranging) and orthophoto point clouds [6-10]. By and large, a GIS is merely a part of a general tradition of digital data handling and spatial representation in different scales - global, national, regional, and local extents. What is more, there has been rapid growth of both remote sensing, and GIS tools involvement in monitoring urbanization and relevant environmental changes and in urban management over past few decades. These techniques and technologies have been developed with simultaneous elaboration of the city simulation capabilities provided by the methods / rules / interfaces created for various modeling-visualizing software products $[1$, 2, 11-15].

We may consider a $3 D$ object / feature model as a core entity of the GIS output made from the input outlined above. Such a statement becomes even more evident, while the discrete objects of urban environment are considered, when we are speaking about a 3D city model. In general, three-dimensional modeling appeared to be a key approach within the common geoinformation concept, especially, taking into account the applied perspectives of this concept $[5,16-23]$. We have already outlined our understanding of a 3D city models in some papers published before $[3,4,24,25]$. We do understand the three-dimensional city model of urbanized environment as an entity, which natural analog is located within $3 D$ urban space characterized by usual urban features and structures with buildings as the dominant features among them.

The Automated Feature Extraction (AFE) from satellite images of high resolution and from datasets resulted from LiDAR surveys, which are obtained by strips and finally combined as $3 D$ Point Clouds, is the key tool that generates $3 \mathrm{D}$ city models. Methods and techniques that extract building models in any alternative ways are an insignificant research field. The AFE from LiDAR point clouds is a research and development topic of great interest as it is very profitable for various applications of 3D city models such as urban planning, urban disaster management, energy sector, infrastructure network planning, different Smart City projects, and solutions with 3D city models in some other domains. This automated procedure is an extremely challenging task for surveyors and researchers, since it means 3D automatic mapping of the urban environment, which is of the high complexity. What is more, exactly LiDAR data have become for two recent deca- 


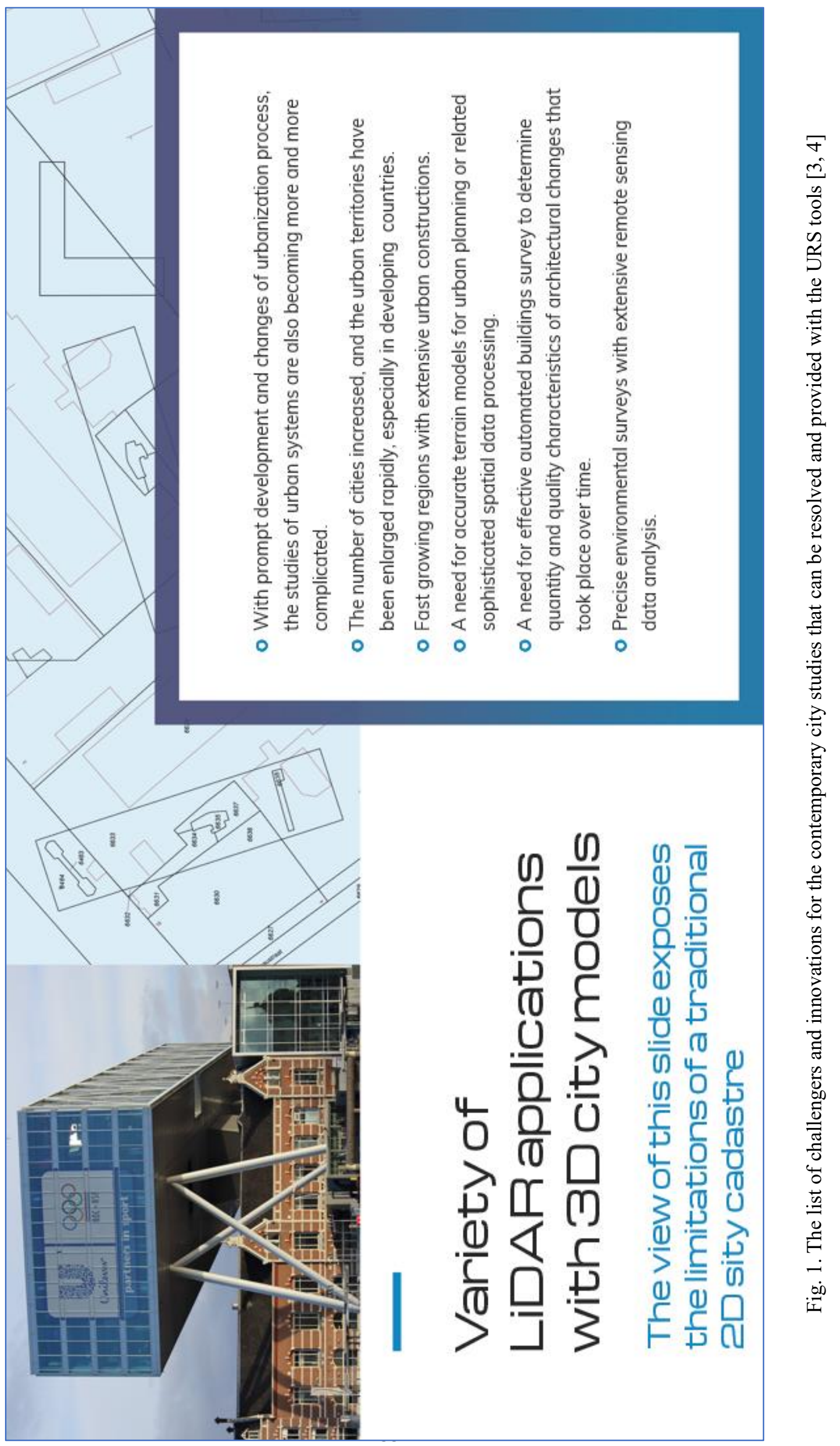


des a reliable alternative (to satellite remote sensing) data source for building detection, extraction and reconstruction using different $\mathrm{R} \& \mathrm{D}$ approaches and algorithms [20, 26-30]. Therefore, the automated building and other anthropogenic feature extraction from LiDAR point clouds simultaneously with the relevant digital elevation model (DEM) generation is one of the most challenging research and development goals for urban studies as well as for support the urban environment by means of digital technologies and information networks.

The key research goal of this text is to outline our original contribution to the algorithmic content of the automated feature extraction upon the urban environment modeling, as well as to represent the original web-software for urban studies.

AFE methods in the building detection, extraction and 3D reconstruction within the LiDAR pipeline: a thematic overview. The overall $A F E$ algorithmic approach. Almost all LIDAR devices are either Airborne lidars (ALS, Aircraft Laser Scanning), or Terrestrial (vehicle based) ones [24, 25, 31]. The latter is also named Mobile Laser Scanning (MLS) devices. Commonly LiDAR remote sensing is the set of techniques used to obtain initial information for further processing due to the topographic surface, vegetation, and various human fea- tures at certain distance from scanning sensors (buildings, bridges, roads, powerlines, etc.). One of the key contributions of LiDAR data and its processing results is to increase human knowledge of the natural landscape and the mentioned human infrastructural features and hence to improve their usability and increase their profitability. The feature extraction from raw lidar data, LiDAR Point Cloud segmentation, and rooftop modeling, all have been one of the main topics of discussions in relevant thematic domain during a couple of last decades [31-39]. Now, AFE is still a vitally crucial part of what is being done and what professionals are trying to do better within the international LiDAR community. How have specialists further progressed with AFE in recent years?

It is widely accepted that a key issue for automated feature extraction is to provide a bridge between the mobile LiDAR and the airborne LiDAR, and vice-versa. Since we are not completing an extended overview paper by this text, but otherwise only looking through several works of the recent ten years, we have only to express a single quite trivial idea proceeding from our own $\mathrm{R} \& \mathrm{D}$ efforts, that the composite models of urban extracted features may be accepted as the most advanced ones (Fig. 2 from [25]):

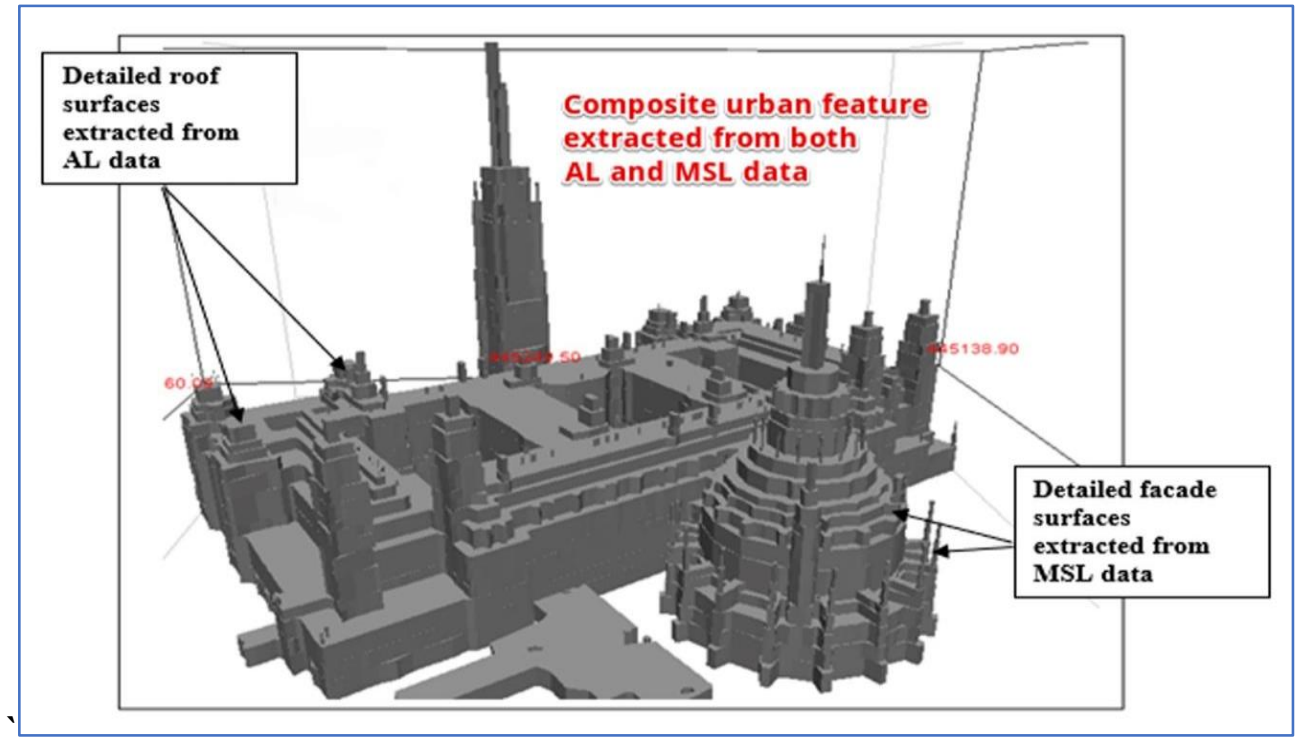

Fig. 2. A composite model (ALS+MLS) of urban features extracted from a LiDAR Point Cloud of the downtown of Ottawa [24, 25]

Just according to ALS / MLS joint surveying technique the automated derivative data extraction for 3D urban models has become a crucial research topic beyond the Photogrammetry. The case is, that additionally to aerial images Photogrammetry traditionally deals with 3D building model generation from airborne-mobile photogrammetric point clouds, just as LiDAR surveying technique does with similar datasets. After all, the innovative sensor technology and its lower cost in comparison with its predecessors has expedited LiDAR involvement in research of urban environment. Probably, the key reason of this fact is that circumstance, according to which ALS / MLS scanners can deliver point clouds with density values of tremendous range (from 1 up to several hundred points per sq. meter). Even with such point density of this lower edge of the range, it may be possible to detect buildings, their approxi- 
mate boundaries, and other urban man-made features. It is possible to generate those models that correctly resemble both facade, and roof structures. Corresponding methods of ALS / MLS surveyed data processing for building detection and reconstruction have been proposed [38, 40-47].

The complete algorithmic content of AFE issues with ground and vegetation detection, and manmade feature extraction has to employ either single-, or multi-return ALS / MSL range and intensity information. So called hierarchical terrain recovery algorithm can reliably be distinguished between ground and non-ground points by the "adaptive and robust filtering" approach [48]. It is necessary to consider the whole range of initial data to estimate high quality DEM for further AFE procedures using this so-called hierarchical strategy. Road lines can be identified by classifying signal intensity and elevation data. Not only buildings, but also network features can be extracted then. For example, such man-made features as the road networks can be derived using a special transformation technique, and then verified with road lines and DEMs obtained from a LiDAR point cloud. Further we can obtain the attributes of road links such as their width, length and slope by computing some derivative information. Other man-made features as building models normally should be created with the higher level of accuracy.

The general work-flow of the building model creation can be supposed as follows on the base of those literature sources we have already referred to. At its first stage, the building footprints (building base boundaries) should be detected by segmenting elevation data obtained from LiDAR for two general classes: ground class and non-ground ones. The bare ground as a grid is delineated upon this step. A wellknown, so called "sequential linking technique" is often suggested to reconstruct building footprints into regular polygons. These polygons then should be improved to reach the cartographical quality [49-51].

At the second stage, the prismatic models should be generated for those buildings which roofs are flat, and polyhedral models should be generated for those buildings which roofs are non-flat.

At the third stage, the vertical wall rectification procedures should be applied if there are enough MSL or other correcting data in the relevant LiDAR geodatabases. These three stages would overlap almost any LiDAR data processing workflow. Most urban attributes of these building models are obtained from ASL-MSL data. All corresponding algorithms, that conclude the three stages workflow outlined above, should be tested using several geodatabases of varying earth surface type, vegetation coverage type, urban area type and LiDAR point density.
We completed below the general summary of these few overviewed algorithmic results. This summary demonstrates that in many urban areas the derivative digital elevation models accumulate most topographic details and remove non-ground features reliably. The road network features are depicted well enough even in densely built-up areas. The extracted building footprints are appeared to have enough positioning accuracy. This value may be equal to the accuracy obtained from data surveyed in field trips, and this surveying technique in some cases is a routine procedure of LiDAR data accuracy evaluation $[31,52,53]$.

The overall algorithmic approach described above according to the literature review already made may be summarized like follows (Fig. 3).

One issue is quite evident for now from that part of the literature review, that has been already done: if the ALS automated procedures and techniques did ground their efficiency quite a few years ago, the MSL tools still have to pass a certain way in developing automated procedures to prove their AFE efficiency. Our own experience of MSL data processing outlines, that it is possible to obtain quite impressive results by the proper arrangement of the MSL algorithmic pipeline - two visuals of Fig. 4 represent both urban (A), and natural (B) environments with buildings and infrastructures.

Finalizing general AFE issues considered above, it is necessary to emphasize that despite LiDAR data are usually dense, quite accurate, and representative, because of their limited accuracy the segments of a relevant point cloud do not precisely lie on a geometric plane, but are scattered within some plain near the building facets (roof and walls). The point deviations from the mentioned mathematical plane conform to a Gaussian distribution, which is centered at zero. That is why, a separate building with a multi-facet roof and numerous wall planes can be represented by a 3D Gaussian mixture model (3D GMM) [54]. There are references in the literature that 3D GMM can more successfully do with roof-plane intersections, than any other approach (e.g., RANSAC algorithm) can do [31].

All mentioned in this brief literature review approaches normally supply a 3D city model with relatively satisfying reconstruction at its roof and wall levels. These models can be generally divided for two significant classes: either high-polyhedral models, or low polyhedral ones. A model sample, which belongs to the first class has been already represented in our text above (see Fig. 2).

\section{Feature detection, classification, and segmen-} tation. From our point of view, most feature detection, segmentation, and classification algorithms use only a few basic procedures described below, some of these procedures have no definitive frameworks, 


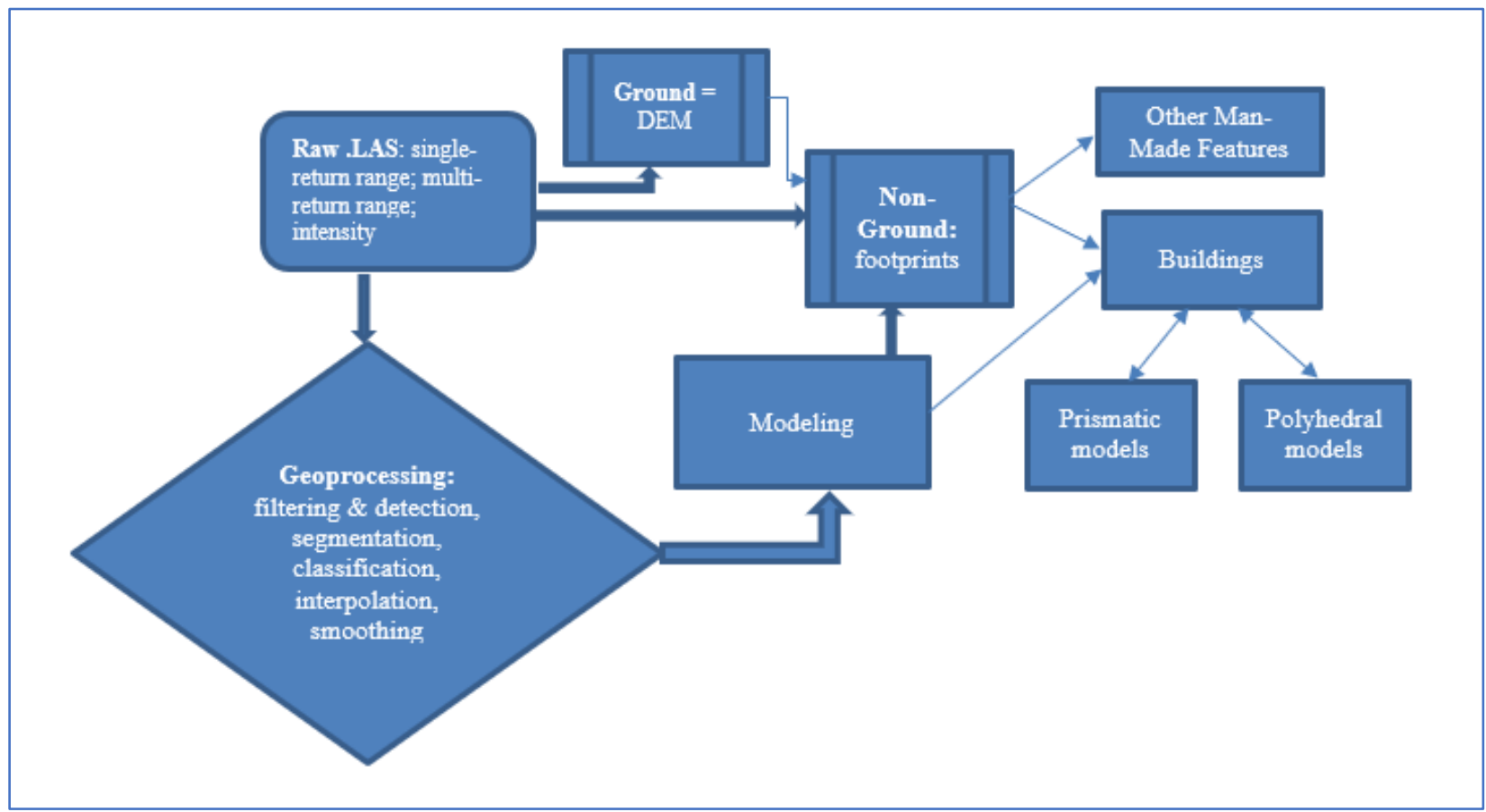

Fig. 3. The overall algorithmic approach for automated feature extraction (the visual originally completed by the authors of this paper)
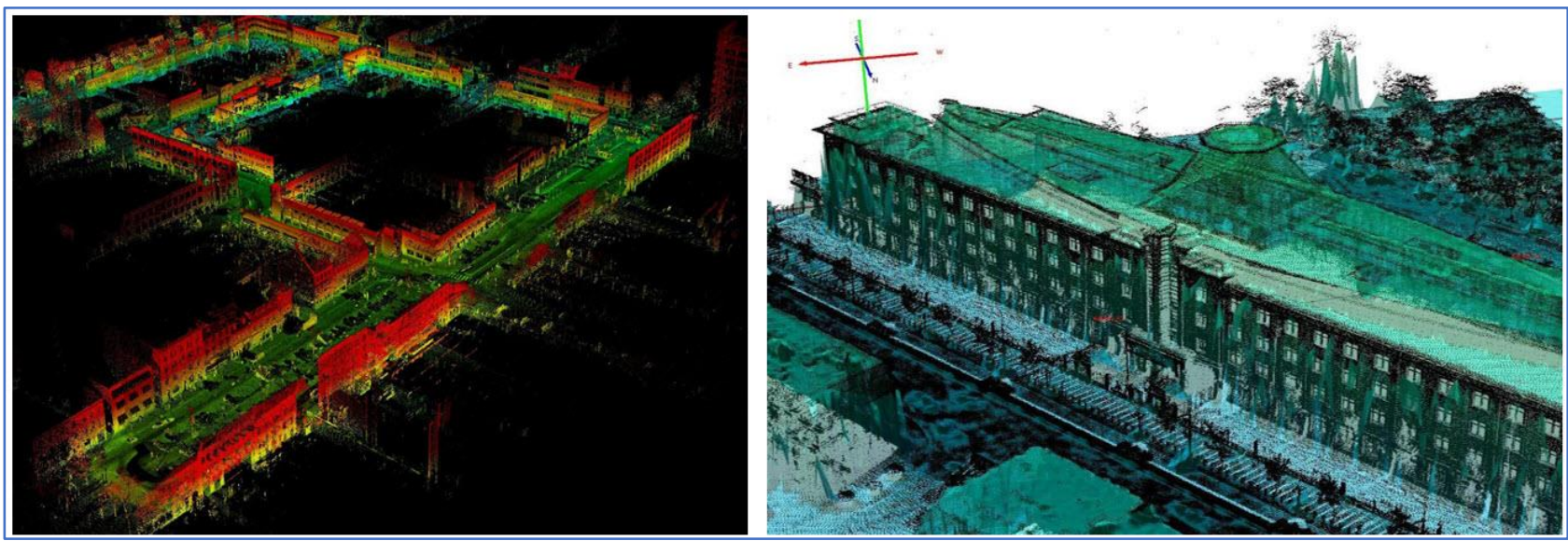

Fig. 4A. Urban survey with MSL: $1^{\text {st }}$ visual - scanning reconstruction of the route of President Obama's visit to Ottawa; $2^{\text {nd }}$ visual - reconstructed MSL facades of the Canadian parliament building.

Original illustration of this paper authors
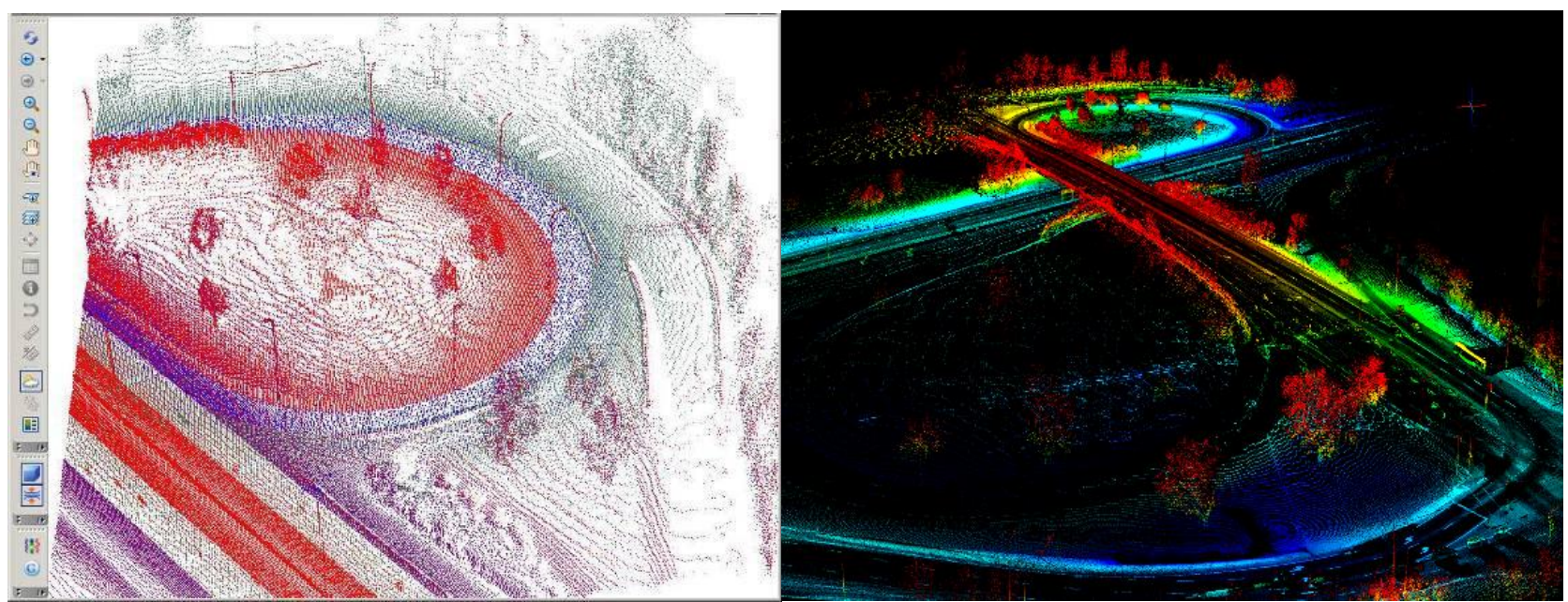

Fig. 4B. Environmental survey with MSL processed results: ground cover, low and high vegetation belt, surface human infrastructure - roads in the countryside. Original illustration of this paper authors 
until there are some specific data processing procedures for them to be involved. All procedures, we refer here to, are outlined in our visual above (see Fig. 3), and these procedures are as follows:

- Filtering / distinguishing technique normally provides eliminating unwanted measurements, and detecting bare ground surfaces from a mixture of ground and upper-above-ground measurements. To distinguish points located on buildings, trees, and a lower vegetation belt from those that should be on the ground, normally applied order statistics, morphological filtering algorithms (we have already mentioned above), and statistical weighting functions [55]. Additionally, raw .LAS files may be processed to remove rough outliers, but nonetheless preserving the discontinuities between the generated surfaces [56, 57];

- Detection and Classification. The algorithmic procedures search to detect the best mathematical approximations of discrete features in 3D point clouds, for example, the best mathematical plane, which, what is significant, cannot be always a roof plane. We can only detect those building properties that can be detectable by LiDAR sensors. In this meaning the buildings should be considered as the constructed features located above the bare ground with vertical walls extending over some height and covering some area. Their external surfaces are complicated, but always distinctive from coverages of nonbuilding features. Usual difficulties of the above-ground point detection are normally caused by the topographic surface natural complexity. With LiDAR point data detecting 3D planes becomes crucially necessary. In this aspect, the Hough transformation detection has been extended to 3D data arrays [58, 59]. The main idea is that the procedures of the 2D Hough transformation is outlining a point set, defined initially in the Euclidian space, in another space. This transform allows detecting the points composing both basic specific geometric primitives.

Classification is normally used to distinguish among various types of ground features (e.g., buildings, other human features: roads, bridges; grasslands, shrubs and trees) to group them into different cluster classes of points by, for example, applying to them pattern recognition algorithms, such as $\mathrm{k}$ means, ISODATA, Bayes classifier, and other [6062]. Shape parameters measured can be applied to distinguish between buildings [63, 64]. Providing adequate separation of lower and higher vegetation belts from buildings may be the most challenging problem in LiDAR-based classifying research. Quite a few potential solutions have been suggested, in- cluding applying NDVI thresholds [65], the first and the last returns differences identification [66], applying roughness metrics [67], and using the intrinsic dimension [68].

The procedures on the detection step can be summarized well enough by the following description [69]. Raw points are classified into two categories: ground points - where are ground itself, infrastructural networks (that ones, which are above the surface) and low vegetation belt (bushes) that are below an altitude threshold, and non-ground points, which represent upper-elevation features (such as buildings, trees, and some bridges) above this parametric threshold. The "ground mask", that is actually a building mask - a footprint - is generated by the ground points. Separate buildings and trees are received as clusters of pixels black colored in the building footprint. Those trees, which are with low density canopies should be eliminated. The point coplanarity should be evaluated on this step. This value for each individual non-ground LIDAR point with its neighbors is estimated basing on its Delaunay neighborhood. The plane segments are extracted from the non-ground points on both separate buildings, and trees. The segments extracted are refined then with a conventionally proposed procedure. At the end, the false planes on trees are eliminated on the base of metric and topological information, such as area, and supplementary neighborhood characteristics, such as the out-of-plane points presence within the single planar boundary.

- It is possible to refer to the complicated segmentation methods based on neural networks [70], but, nonetheless, there are more tradition$\mathrm{al}$ and straightforward ones against them. Segmentation usually means the separation of LiDAR data array into homographic patches by the way of outlining different topologic, geometric, or texture structures (e.g., roads, bridges, buildings, and vegetation) by applying threshold introduction, clustering technique, limit detection or so-called perceptual organization algorithms [26, 71, 72]. The segmentation procedures can be clearly demonstrated with the next example of their involvement into the building roof extraction $[26,65]$. Basing on the topography altitude recorded in a DEM, the raw .LAS points are separated into two categories. The first category contains the ground points forming a "building mask". The second category contains non-ground points that are grouped with this building mask. A point cluster should represent a single building or a tree. By segmentation procedure, the planar roof segments are derived from each cluster and refined proceeding from the coplanarity of points and their localization. Planar surfaces 
that cut trees are removed using characteristics, such as a parcel area and point altitude difference.

Feature extraction and reconstruction. Building detection and extraction can be considered as two sub-procedures that go before finalizing subprocedure of feature reconstruction.

Building detection for consequent extraction:

- Direct building detection. As we showed in the text building detection before its extraction defines the placement of building footprints, which are employed by subsequent reconstruction. This step should distinguish buildings from vegetated regions either of a high vegetation belt, or low one. For the time being, general building footprints can hardly be detected completely automatically with high precision. Building constructions can be detected by layering range data and examining the hierarchy of consecutive feature segments [73]. The range data can also be relatively easily employed to improve the analysis of image data for detecting buildings in urban territories and assist to detect the objects covered by shadows [74]. Nonetheless, this method is applicable in flat urban areas only;

- Building footprint reconstruction may be a key step for the final successful output, but most existing relevant algorithms work, as a rule, with vague assumptions only. These assumptions restrict footprints to simple geometric shapes, for instance, rectangles or the polygons of low quality [58, 74]. Another algorithmic class does not make such assumptions, instead it often gets distorted boundaries on the base of edges detected by DEMs generated from raw .LAS [75]. Nonetheless, these boundaries can be refined, normally - by applying so-called "set of geometric regularity constraints" [57, 76]. We have to mention the solid algorithms are not available for this processing stage footprint reconstructions. It may be some possible solutions in developing robust and efficient methods based on Hough transformation mentioned in the text above;

- Distinguishing building footprints from vegetated regions. In such a case the classification deals shape measures taking into account the geometric regularity constraints [74] or the raw LiDAR data roughness. These measures also are not very reliable either for complicated 3D urban scenes, or for densely forested areas, because they limit the detectable buildings to a narrower spectrum. In general case, shape measures normally make use of simple geometric properties such as area and perimeter. Nonetheless. In a case of the complex building roofs we may need to calculate the roughness measures. We have to take into account, that since the building roofs must be solid surface, the application of multi-return range information can benefit in distinguishing of buildings and vegetation. Moreover, it is a wellknown fact that LiDAR cannot pass through solid surfaces, therefore it gets for them a single return only. What is more, the first and the last returns are equal in altitude at solid surfaces, but these returns are different at vegetated regions. Nonetheless, LiDAR obtains rather similar effect at building boundaries, and we can compare it with that one at vegetated areas.

- Building reconstruction. By default, the building reconstruction procedure recovers the geometrical characteristics of the roof and walls of a single building allocated precisely [26]. Quite often this term "building reconstruction' means recovering some building elements, first of all - roofs, which are reconstructed most often at first recovering attempts.

When classified, extracted, and reconstructed from raw data, a set of building footprints usually includes numerous buildings. For reconstruction 3D modeling outputs, individual buildings should be segmented, as we already outlined above. For these aims, the widely used segmentation techniques can be applied, which is based on clustering approach [77]. Quite a few cluster models (for example, connectivity, centroid, and distribution ones) as well as clustering algorithms (for example, hierarchical clustering, k-means and expectation maximization) are widely applied [78]. Thus, a region growing approach was proposed once to cluster similar points into the same building through iteratively collecting these points within a sliding window [79]. The convex hull algorithm applied in this case [79] was modified later in two following examples $[62,80]$. It derived individual building hypotheses with traced boundaries using this modified algorithm. Nonetheless, all these methods outlined above are considered as sensitive to noise and quite expensive to implement [77].

The non-building features can be misclassified as buildings at the stage of detection. Many algorithms apply supplementary data, for instance, ground plans and maps of large scales to improve the reliability of building footprint boundaries [19, 20, 57].

EOS LiDAR Tool (ELiT) and our key original algorithmic approaches to the AFE issues. In general scope, dominant advantages of the AFE approach, which can be outlined from the thematic overview provided above, may be summarized as the following ones [4]: 
1) High accuracy of the geospatial information gathered by a LiDAR survey. Collected Point Clouds illustrate a spatial location of real natural / technogenic features in minute details, while even an extremely small peculiarity may make difference, and it can drastically change the whole view of a 3D Scene in a GIS interface;

2) Within this approach geospatial data can be collected promptly within a certain AOI, and these data are expected to be highly attractive from the point of view of its cost; In this way, it is possible to provide a quite accurate geospatial monitoring of any large areas; consequently, this circumstance allows to identify various urban change detection operations from multitemporal LiDAR data sets;

3) LiDAR data processing technique may be the only one, that represents a composite view of the environmental modeled picture, because it deals with a collection of raw data concerning all the features on the earth ground, that generally can be divided for three feature sets: inanimate static nature, vegetation cover, and man-made constructions, mainly - buildings.

All authors of this paper lead the algorithmic elaboration and software development due to $\mathrm{Li}$ DAR data geoprocessing at the EOS Data Analytics company (https://eos.com) [81, 82]. While constructing and linking all necessary algorithmic steps for extracting features and reconstructing buildings, we do accept according to those key points of the thematic overview made above, that the LiDAR remote sensing mainly is the approach employed for geoprocessing the information about the topographic surface, vegetation, and mentioned technogenic features of the human infrastructure scanned at the certain distance from a surveying point. Normal data resolution of our geoprocessing lies between 5 and 140 LiDAR points per $\mathrm{m}^{2}$.

The software developed on the base of our already published multifunctional research approach [4, 24, 25, 81, 82] - ELiT (EOS LiDAR Tool) Serv$e r$, as a web-based application (WBA) with a cloud platform support, implies implementation of the following basic ELiT functionalities within the distributed information system (Fig. 5):

- Building Extraction tool (BE- a sub-page Building Extraction of the Tools page) provides building detection and extraction as various sub-procedures that go towards finalizing subprocedure of building reconstruction for highrise buildings of urban areas; $B E$-functionality provides the High Polyhedral Modeling (HPM) approach, what implies the generation of building models consisting of numerous polyhedrons, and due to this fact, the relevant models can be considered as "heavy-weight ones"; this building model may be generated from up to one hundred and forty thousand of points;

- The Building Extraction Rural Area tool (BE$R A$ - a sub-page Building Extraction Rural Ar$e a$, which is on the Tools page) provides the Point Cloud segmentation and clustering procedures of building detection and extraction of low-rise buildings through rural areas and suburbs; the BERA tool implements the Low Polyhedral Modeling (LPM) approach, which is based on procedures of planar segmentation and clustering of LiDAR point clouds rather, than on their classification (the case of HPM); building models produced are composed of not many facets, and the number of points intended for a single model generation is limited by a number of five thousand; such a number may be obtained by adaptive thinning at the cost of details;

- The Change Detection tool $(C D)$ is normally implemented by a sub-page Change Detection of the Tools page. It is a software technique, which automatically detects block-, district-, and city- scope alterations. These changes normally happen through urban areas over some period of time. This technique detects locations of changes in positions and shapes of buildings as 3D models with additional spatial information. Normally two Point Clouds (the temporally primary, and the temporally secondary ones) are compared, and the difference between them is outlined as a BE-model - a result of the high polyhedral modeling;

- The DEM Generation Tool (DEM-G as a subpage of the Tools page) provides a regular matrix creation of topographic height, in this way it makes a grid. In other words, a series of irregularly spaced elevation points are acquired, from which uniformly spaced elevation markers are interpolated. Hence a DEM is created, which we understand as a synonym of a digital terrain model, which represents the bare earth terrain with uniformly spaced $z$-values;

- The relevant web-API has been created and a user-friendly web-interface has been designed for uploading, storing, processing, analyzing and downloading geodata;

- Modeled results can be directly exported to 3D visualization models in .KML, .COLLADA, and .glTF formats. These results are displayed through ELiT Viewer, if processed by ELIT Server, and are visualized at ELiT Geoportal, if they are resulted from cloud computing with Amazon Web Services;

- A tiling visualizing strategy is employed with Cesium 3DTiles library, which allows to visualize almost any large 3D city all over the world 


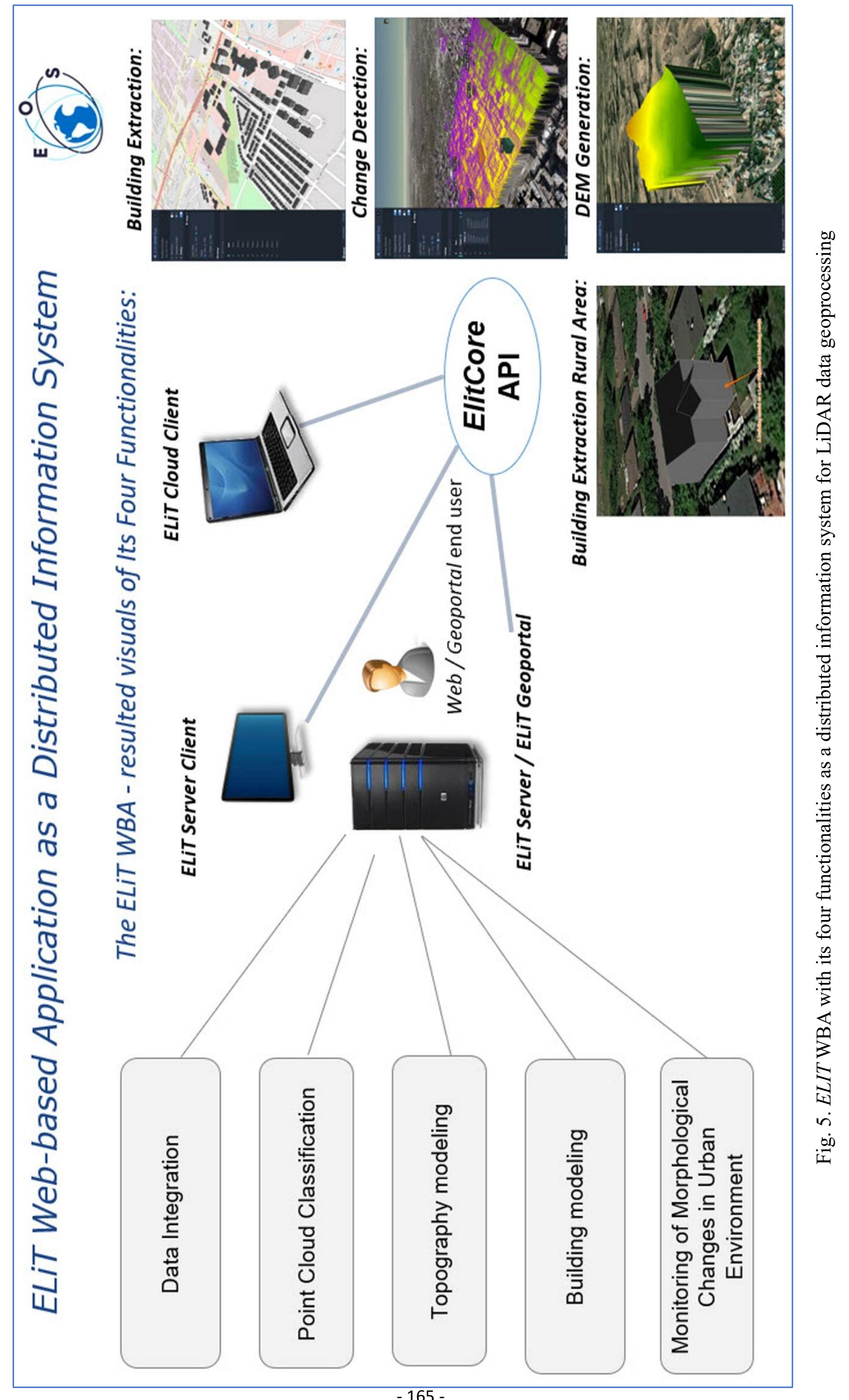


with backgrounds like, e.g., Open Street Maps of digital virtual globes like Google Earth or Cesium Virtual Globe.

High Polyhedral Modeling provided by the ELiT Building Extraction (BE) tool. Some basics of this technique have been already introduced by the authors of this paper in their earlier publications $[4,24,25,83]$. Until now the most detailed introduction of our original HPM frameworks has been presented with an explanatory flowchart in [25]. In this text below we have placed some other, more simplified representation of the HPM algorithmic pipeline in comparison with [25] - Fig. 6.

It is reasonable to add to those summarizing remarks made in the previous section of this paper (a thematic overview) a statement about earlier introduction of HPM methods in comparison of LPM ones into a variety of AFE solutions. With increasing availability of LiDAR data with various density and improved accuracy many methods of 3D build-

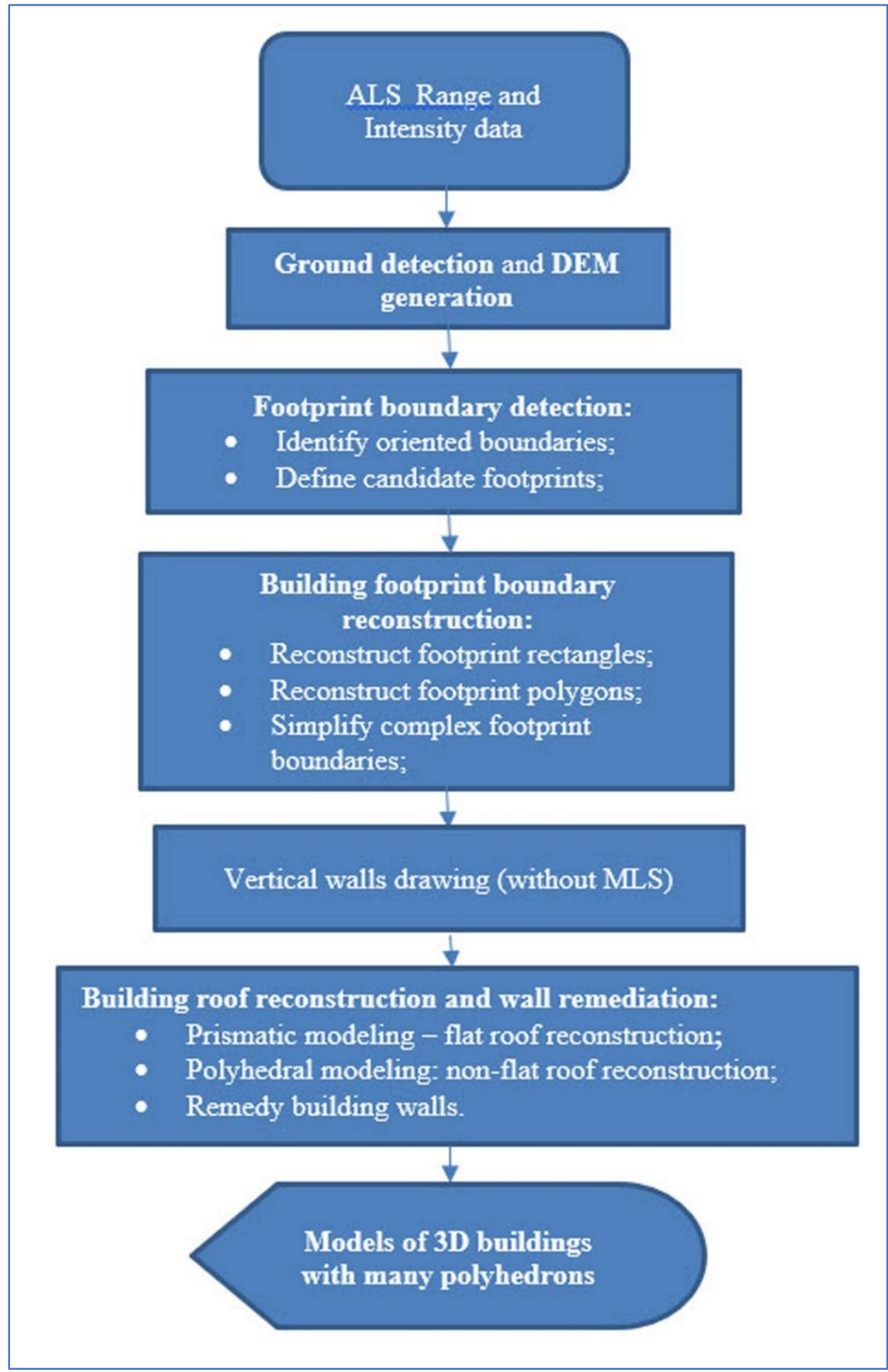

Fig. 6. ELiT algorithmic flowchart of building detection, extraction, and reconstruction within the HPM frameworks, while MLS data processing is not involved 
ing reconstruction have been proposed as a technique that fits in the HPM outline [26-28, 43, 44, 64, 84]. These HPM-methods, and this follows from our thematic overview made above, can be fulfilled by three sub-procedures, i.e., building detection, building extraction, and building reconstruction [48, 55, 85]. All three sub-procedure may not be evidently distinguishable. Complete automated process of building extraction only within HPM-frameworks may not be reliable yet for practical applications in majority of cases, because of the great complexity of actual architecture in urban downtowns, which is resulted in simultaneously dense and scarce point clouds a LiDAR survey ended in a given AOI.

Both an operational sequence, in general, and our original algorithmic flow-chart outlined above are to a certain extent a summarization of those HPMimplementations, we have referred to above. We have to emphasize once again, that suggested flowchart differs from one published before [25] by that, it does not involve MLS data processing. Several preliminary classifying steps should be implied (Detection of basic classes according to the standardized lidar Point Cloud classes, if they are in a given cloud, or not; Classification based on point coplanarity; Delineation of preliminary footprints, which differ from "candidate footprints" mentioned in the third block of a flow-chart).

Then, after necessary preprocessing (a block of ALS Range and Intensity data), all points are ultimately separated for ground and non-ground ones (a block of Ground detection and DEM generation), what is finalized by both a digital surface model (heights of a ground + features) (DSM), and a DEM (only ground heights) generated.

The whole building extraction with following reconstruction pipeline actually starts from detection of feature footprints on a generated DEM (a block of Footprint boundary detection). This procedure is normally completed in two steps: an identification of oriented footprint boundaries and a definition of candidate footprints (they are another entity in comparison with "preliminary footprints" drawn on the preprocessing steps). The candidate footprints are extracted as No Data holes in an obtained topographic grid.

Through further processing building footprints are reconstructed as quadrangles, rectangles, or regular polygons (a block of Building footprint boundary reconstruction).

"Artificial" walls are extrapolated from footprint boundaries (a block of Vertical walls drawing (without MLS)).

Building roofs may be raised from these footprints outlined and corrected supplementary by the same ALS point cloud data. If a building has a flat roof, it should be modeled as prismatic shapes, while a building with some complicated shape should be modeled as a polyhedron (a block of Building roof reconstruction and wall remediation). As already emphasized above "High Polyhedral Modeling" means that primarily reconstructed building facets and components (roofs, walls, outhouses) consist of many polyhedrons in comparison with that, while building models can be combined from few polygons only [20, 41, 86]. According to understandable reasons, these models are normally extracted and visualized as the heavyweight entities (from up to 20 to 150 thousand of points processed per a model of buildings). Therefore, necessary smoothing and noise removing should be mandatory provided. For these purposes our update of a Delaunay refinement algorithm [87] has been used. The relevant "covering Delaunay TIN" is involved in algorithmic sub-blocks of Polyhedral modeling: non-flat roof reconstruction and Remedy building walls.

All algorithmic blocks and sub-blocks mentioned in this paper section are provided for processing ALS data only and reconstructing only key building components (roofs, walls, outhouses, etc.). A typical HPM-model has been visualized on Fig. 2 in the text above.

Low Polyhedral Modeling provided by the ELiT Building Extraction Rural Area (BERA) tool. Main basics of this technique also have been already introduced by the authors of this paper in two previous publications [25, 82]. We are developing further and optimizing the approach with this text. Introducing an applied implementation of the LPM technique above as the ELiT BERA tool, we have emphasized, that this technique is grounded on procedures of the point cloud planar segmentation and clustering instead of the point cloud classification, which is basic preliminary procedure in the case of the HPM technique.

Both segmentation and clustering significantly decrease a number of polyhedrons, which pile of a LPM model extracted, in comparison with a HPM model. Therefore, this model is defined as a "low polyhedral" one. Such models are extracted and displayed as lightweight ones (a number of points in a relevant point cloud differs from 5 to 40 thousand of points per a model). Commonly, the low polyhedral modeling frameworks proceed from a number of seminal papers in segmentation and reconstruction of polyhedral building roofs from lidar data published by A. Sampath, J. Shan [32, 33, 79, 88, 89], that is why we named this approach as the $S a S$ methodology. Thus, both segmentation and reconstruction are two key procedures in obtaining the lightweight polyhedron surface models of buildings, what has been proved more than once not only by the authors of the SaS approach, but also in other 
various publications [90-92].

The first step of the SaS implementing pipeline is related to the point cloud segmentation, and it is the eigenvalue analysis provided for each point cloud point within the boundaries of its Voronoi neighborhood. This step both produces the surface normal for every point, and divides all points for two sets - planar points, and non-planar ones. Upon the further algorithmic step, the surface normals related to all planar points should be clustered by using the selected efficient methods. This clustering procedure is being optimized by decreasing a number of clusters through usage of both topological, and geometrical methods for the cluster similarity definition. The building roof segmentation is concluded by a separation of the parallel and coplanar segments using firstly distances between segments, then - their connectivity. Building roof reconstruction within the SaS pipeline begins with composing an adjacency matrix, that outlines the connectivity of delineated planar segments. Building external and internal vertex are determined then by intersecting all roof planar segments and vertical walls that are both external and internal ones. The boundary regularization approach, which finalizes the reconstruction step, helps to obtain building models, which are coherent in their topology and correct in geometry.

The SaS-adjacency matrix is a key issue for delineation of adjacent planar segments within a building model. We have provided the extensive usage of the Voronoi neighborhood for cluster adjacency on the finalizing modeling stage, while the traditional SaS-method implies using the Voronoi diagram on the preliminary surface reconstruction step only. Our key updating contributions to the SaS-methodology are represented in few following subsections of this paper.

Applying the Voronoi diagram for the roof cluster adjacency determination. Exactly one of our most significant updating contributions to the traditional SaS approach lies in the obtainment of optimized adjacency of planar segments, which have been delineated. The original authors employ Voronoi neighborhood for providing eigenvalue analysis, while each point neighbors are being determined. Nonetheless upon computing the cluster adjacency these authors apply a routine distance between all pairs of points using the following formula [33, P. 1562]:

$$
d(\mathrm{P}, \mathrm{Q})=\min \left(d\left(\mathrm{p}_{\mathrm{i}}, \mathrm{q}_{\mathrm{j}}\right)\right) \forall \mathrm{p}_{\mathrm{i}} \in \mathrm{P} ; \forall \mathrm{q}_{\mathrm{j}} \in \mathrm{Q},
$$

where: $\boldsymbol{d}\left(\boldsymbol{p}_{i}, q_{j}\right)$ is a distance between any pair of points $\boldsymbol{p}_{\boldsymbol{i}}$ and $\boldsymbol{q}_{j}$ from clusters $\boldsymbol{P}$ and $\boldsymbol{Q}$ correspondingly.

The problematic issues of the $\mathrm{SaS}$ approach like introduced with (1) arise in a case of nonhomogeneous point density of an initial point could, that has to be clustered and segmented. For instance, a sparse point cloud, that also worsened by the faults of surveying technique, causes the situation, when clustered points may lie far from a cluster boundary, then a distance value (from (1)) fails to be taken into account, while it is checked with a threshold parameter. Consequently, this causes the errored adjacency determination and the wrong model reconstruction. Nonetheless, it may be not so difficult to conclude, that because there are no other lidar points between two delineated planar segments, which would belong to other clusters, these two segments are rather adjacent and their seeming "nonconnectivity" has been reasoned by data gaps only. This challenge can be met by the adjacency determination with Voronoi diagram.

This solution content is like follows. Even if two points are far one from another, and there are no "other (the third one) clusters" lidar points between them, their Voronoi cells do possess common edges, then these two points can be determined by their neighbors. In an opposite case - when there are the third cluster points between this pair of points, the points of this pair are not accepted as adjacent ones even with applying a threshold parameter, which is large enough.

Proceeding from all stated above following to existing references [93, 94], we accept as adjacent ones only those clusters, which points are neighbors of Voronoi diagram, that is their Voronoi cells possess a common edge. By this way, on the one hand, we solve a problem of data scarcity, data gaps and meet a challenge of a sparse point cloud, on the other hand, we obviate a necessity of a necessary threshold value interpolation. By the way, this value has to be both big enough (so that not to remove the actual adjacent clusters), and small enough (so that not to mark non-adjacent clusters as adjacent ones). In this way we increase the applicability of our approach, and decrease its dependency, in particular from the point density and from the equitability of their spatial distribution. What is more, the search of the Voronoi neighbors can be provided faster with our approach, because each point has a computed list of neighbors to be checked for their spatial suitability.

Applying the Voronoi diagram for a separation of the coplanar clusters. Another case of applying the Voronoi diagram is a separation of the coplanar clusters. Once again, the substitution of a search by a distance between a pair of lidar points for $a$ search through the Voronoi diagram allows us determine two dispersed across a space point sets as a single cluster, only if there are no the third cluster points between these two sets of points.

In this way we can process various environmental situation, e.g., that one, when a tree with a 
dense canopy is hanging on a building roof and splitting a roof point cluster for two segments by its shadow. Owing to our approach, we reconstruct one entire plane, what generally improves the finalized results of roof modeling. Moreover, we can efficiently separate adjacent clusters with our approach, even if there are the third cluster points between them. Once again, it saves us from the necessity to customize a threshold parameter manually for the mentioned separation.

Applying the limited Voronoi diagram for avoiding side effects of the adjacency determination. For determining if a pair of one cluster points belongs to one connectivity component, checking is provided, if there is the availability of a common edge for Voronoi cells of these two points. We have to take into account, that in some referred cases this mentioned checking can produce wrong results for those points, which lie on a building boundary [93, 94]. These errored results are caused by characteristics of the Voronoi diagram end cells. For example, the extreme light-colored point (the last point on the right) on the Fig. 7A can be determined as that one, which has the neighbors within the main lightcolored cluster, and therefore it has to belong to the same connectivity component, but evidently it is a wrong solution. The case is, that limiting Voronoi diagram by a building footprint, we are cutting off some Voronoi cells, which lie out of this building boundary. For resolving a situation like this, we introduce so-called limited Voronoi diagram, where the solitary light-colored point, which does not correctly have light-colored neighbors, is determined as an outlier and removed as a noise (Fig. 7B).

In this way, this cluster boundaries are not expanded out of their true position, and false adjacency with other clusters is not generated.

Applying the Voronoi diagram for the awning / overhand identification. A traditional building architectural constituent is either awning, or overhang, as well as both of them. A distinguishing feature of this constituent is a presence of one, or more clusters not vertically adjacent with neighboring roof segments. Thus, there is a necessity to fill this existing rupture, while generating a mandatory closed model. A vertical wall can be added to the model in a similar way it has been done for footprint edges. First of all, before providing this procedure we have to identify the mentioned ruptures.

This identification can be completed through respective Voronoi cells, which lie on both sides of a boundary between two clusters - the light-colored and the dark-colored one (refer to Fig. 7A,B. If a significant difference exists between Z-coordinate values (the heights) of two points, which are the centers of these two clusters, then common edges of two respective Voronoi cells are added to a list of ruptures. By tracing through boundaries of all clusters, we obtain a list of all Voronoi diagram edges, which separate points with significant height differences. A set of continuous lines - nominees for internal walls - can be generated from the mentioned cell edges. The obtained segments are delineated and smoothed, then they can be used for wall generation just as it is normally done with the footprint segments.

Other LPM approaches intended to be implemented. There are various other approaches than $\mathrm{SaS}$ approach within the frameworks of the low polyhedral modeling, and we are going to implement one the most promising of them - the PolyFit approach $[95,96]$. This approach does make emphasis on intersecting the building planes already segmented, then seeking for a necessary combination of intersected planes, so that to get a manifold polygonal surface model, which is boundless and watertight. Therefore, constructing a whole pipeline for the PolyFit implementation in the software, we attempted to employ on a segmentation step the advances of the $\mathrm{SaS}$ approach. At that very time, we are taking into account, that the PolyFit authors prove the effective generation of the light-weighted polyhedron models within this technique. Since our practical PolyFit updates, if described in this text may make it become too lengthy, we are planning to present the description of our PolyFit updates in another paper.

ELiT Geoportal. In our previous publications we have already referred to such robust solution for web-software and on-line services as a web-portal or a Geoportal [82]. The ELiT Geoportal (EGP) is a type of web portal normally used to find, access, and process geographic information (or geospatial information, and LiDAR data referred to AFE is geospatial information too), as well as it is intended to provide the associated geographic services (display, editing, analysis, etc.) via the Internet. The ultimate goal for any geoportal with respect to software marketing is to convert occasional visitors of this internet resource to its warm leads, while in general the geoportals are considered the key application of a distributed geoinformation technology $[97,98]$. We have completed the EGP for this recent year by accomplishing the following various tasks:

$\checkmark$ As a Client's issues (a front-end - FE):

- EGP FE design, including UI options for a processing request;

- Friendly UI of Scenes (including the Global Scene) and Projects (as an example, urban environment of NYC is visualized on Fig. 8 in City GML LOD1 models);

- Primary (point clouds) and secondary (features) data display on FE together with attributive information;

- Advanced FE-visualization with Cesium 


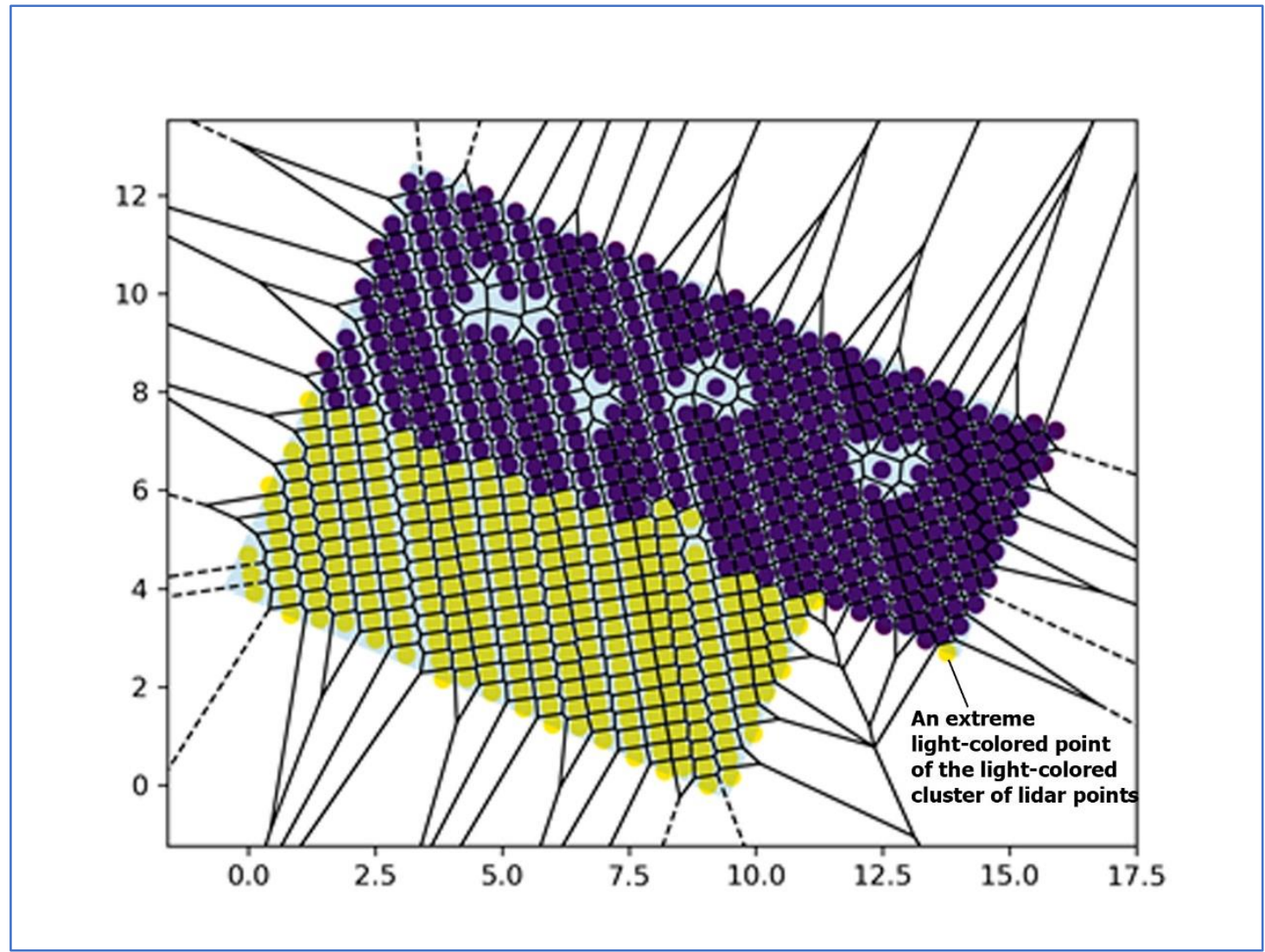

Fig. 7A. A mistaken definition of an extreme point as the one, which has neighbors in the main light-colored cluster. The illustration is made in the picture editor of the programming environment

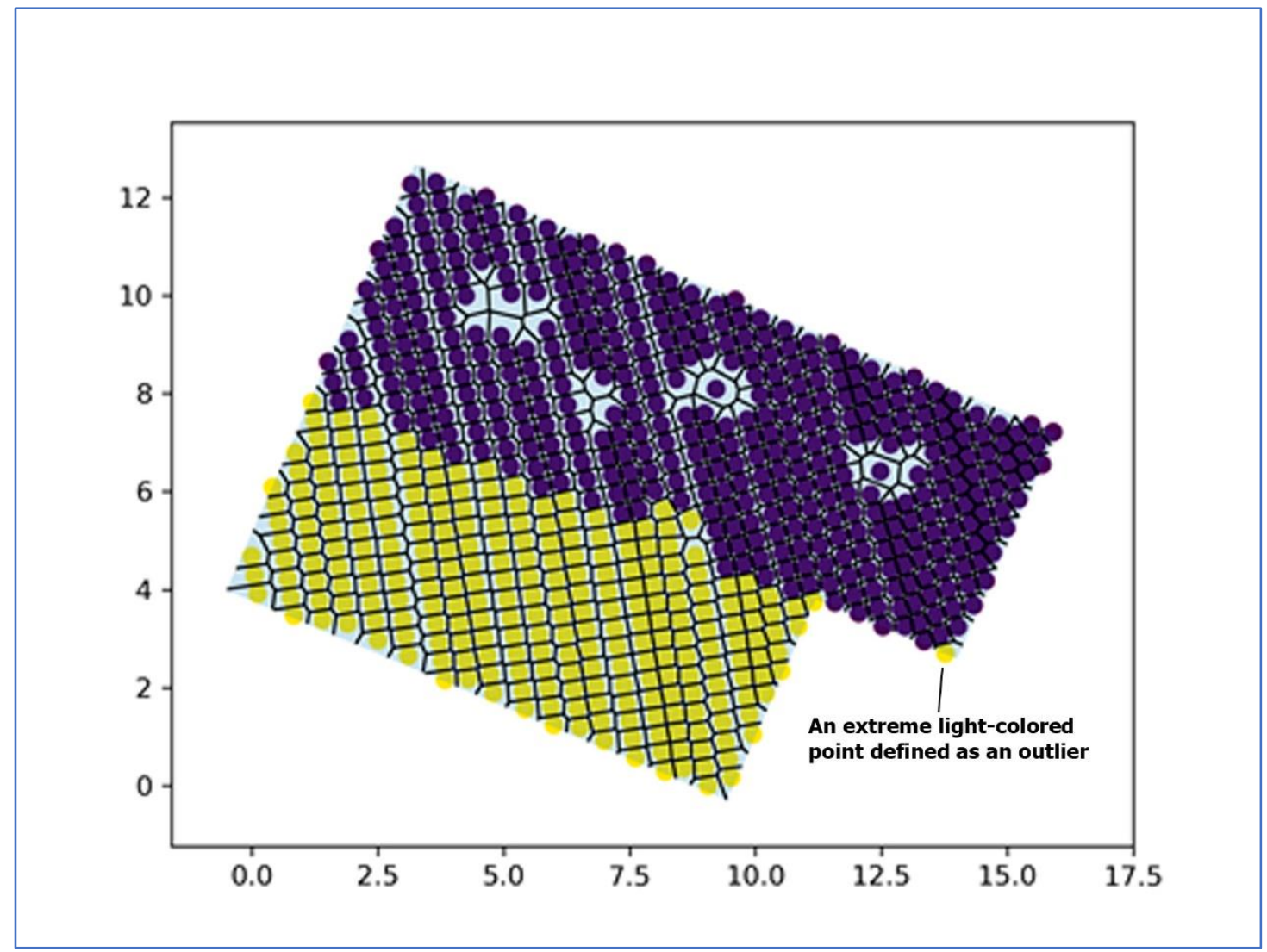

Fig. 7B. A solution of the problem illustrated on Fig. 7A by applying the limited Voronoi diagram 


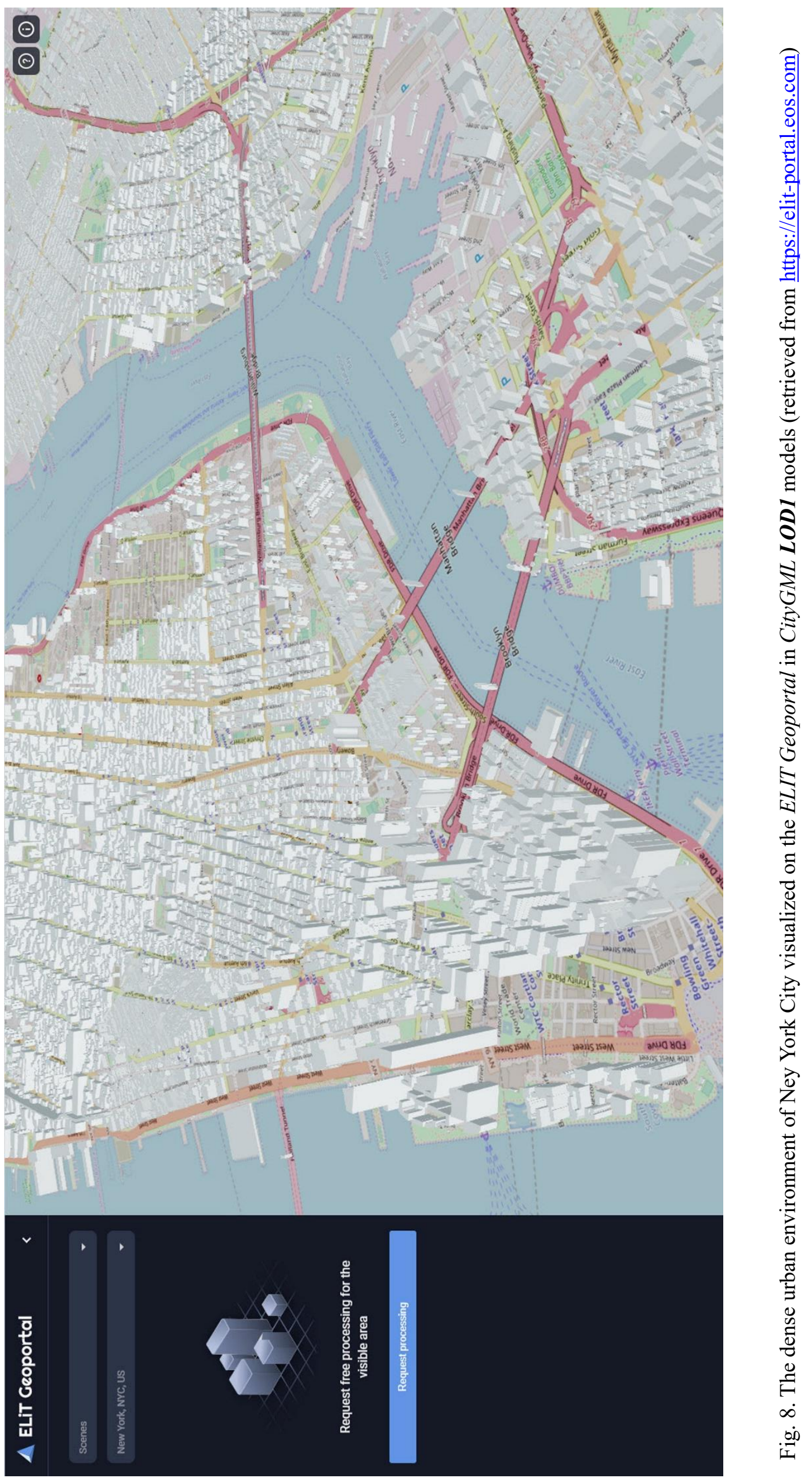


3DTiles;

As a Server's issues (a back-end - BE):

- An architecture of a Geoportal:

- PostGIS database for data storage on BE;

- Web API (Django as a high-level Python web-framework) as an access interface for data usage due to the tasks set;

- Python celery workers employed for lengthy processing operations and for the task parallel implementations for processing acceleration;

- Hosting of LiDAR data;

- Huge projects of urban environment throughout the world located on several servers and consist of terabytes of geospatial information.

We have uploaded to the EGP (https://elitportal.eos.com) both HPM, and LPM modeled results, in particular, a number of projects stored in the AWS Public Dataset of ALS .LAS files for numerous urban environments. In particular, Fig. 9 represents the results of the LPM feature extraction as lightweighted polyhedral models, which display urban environment of not a big city (Lubliniec, Poland) with the complicated rooftops efficiently simulated by the approach presented in the previous section of this paper:
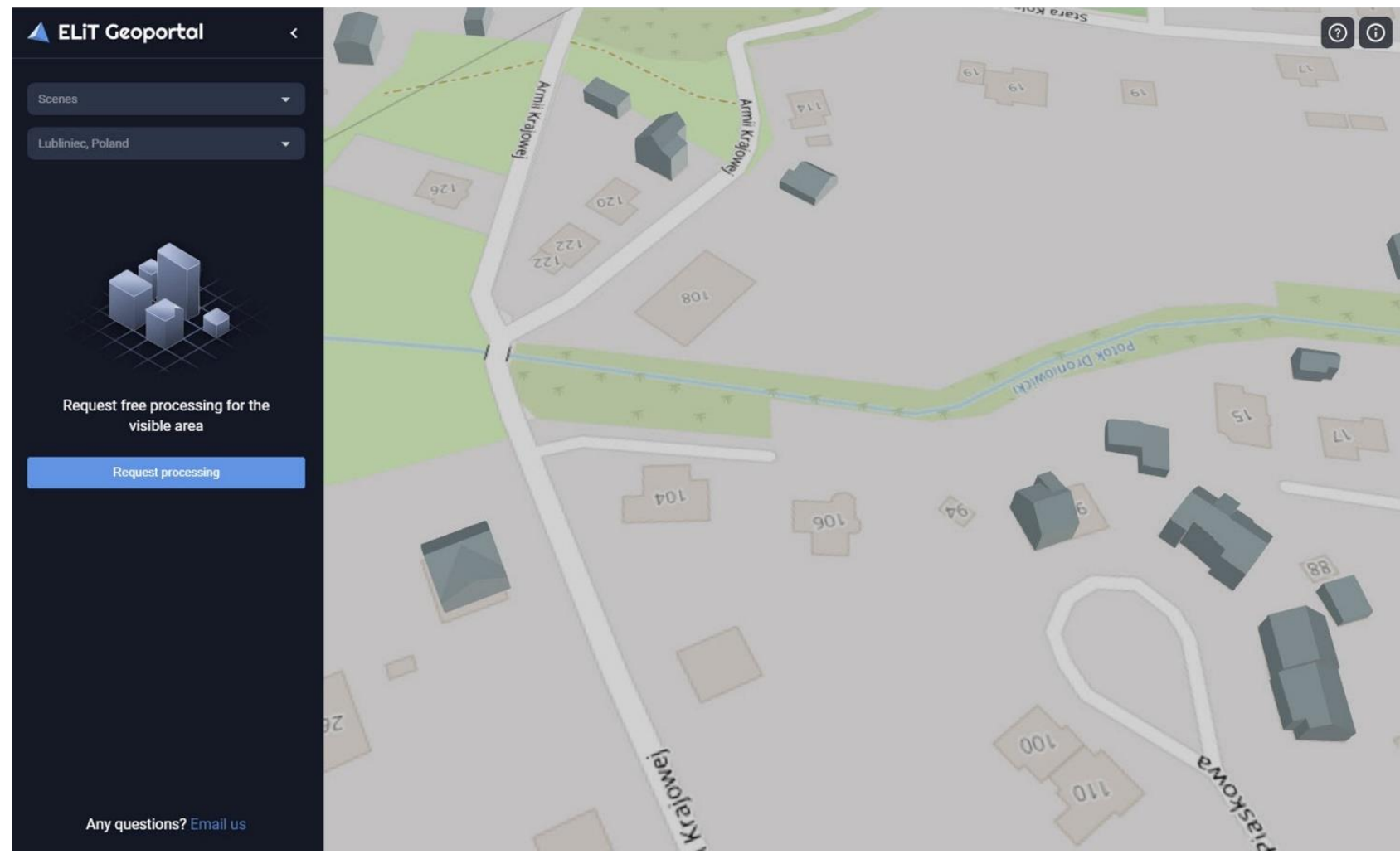

Fig. 9. The thinned urban environment of Lubliniec (Poland) visualized on the ELIT Geoportal in CityGML LOD2 models (retrieved from https://elit-portal.eos.com)

Conclusion and future works. The authors summarized existing advances made within a couple of recent decades in the AFE domain and presented their own updates in two the most large-scale segments of this subject area - the high-polyhedral modeling and the low-polyhedral one on the base of lidar datasets. The overall automated feature extraction technique has been proved to be considered as a highly promising solution for the multicomponent simulation of urban environment, that can be used for various applications, taking into account a number of hot issues requiring the innovative research and technological introductions in urban studies. In this paper, systematic frameworks have been introduced for a number of the following issues: $\checkmark$ In general, a thematic overview of AFE methods concerning building detection, extraction and $3 \mathrm{D}$ reconstruction within a LiDAR pipeline; in particular, a summarized flow-chart of the overall AFE algorithmic approach;

$\checkmark$ Feature detection, classification, segmentation and reconstruction as the key AFE procedures;

$\checkmark$ Web-based multifunctional software, EOS LiDAR Tool elaborated by the paper authors as ELiT Server and ELiT Geoportal;

$\checkmark$ Comparison of high- and low polyhedral modeling as somewhat alternative techniques with some details of our contribution to the $\mathrm{SaS}$ approach of the LPM through using the Voronoi diagram;

$\checkmark E G P$ as an applied service-oriented webtechnology for the ELiT software promotion. 


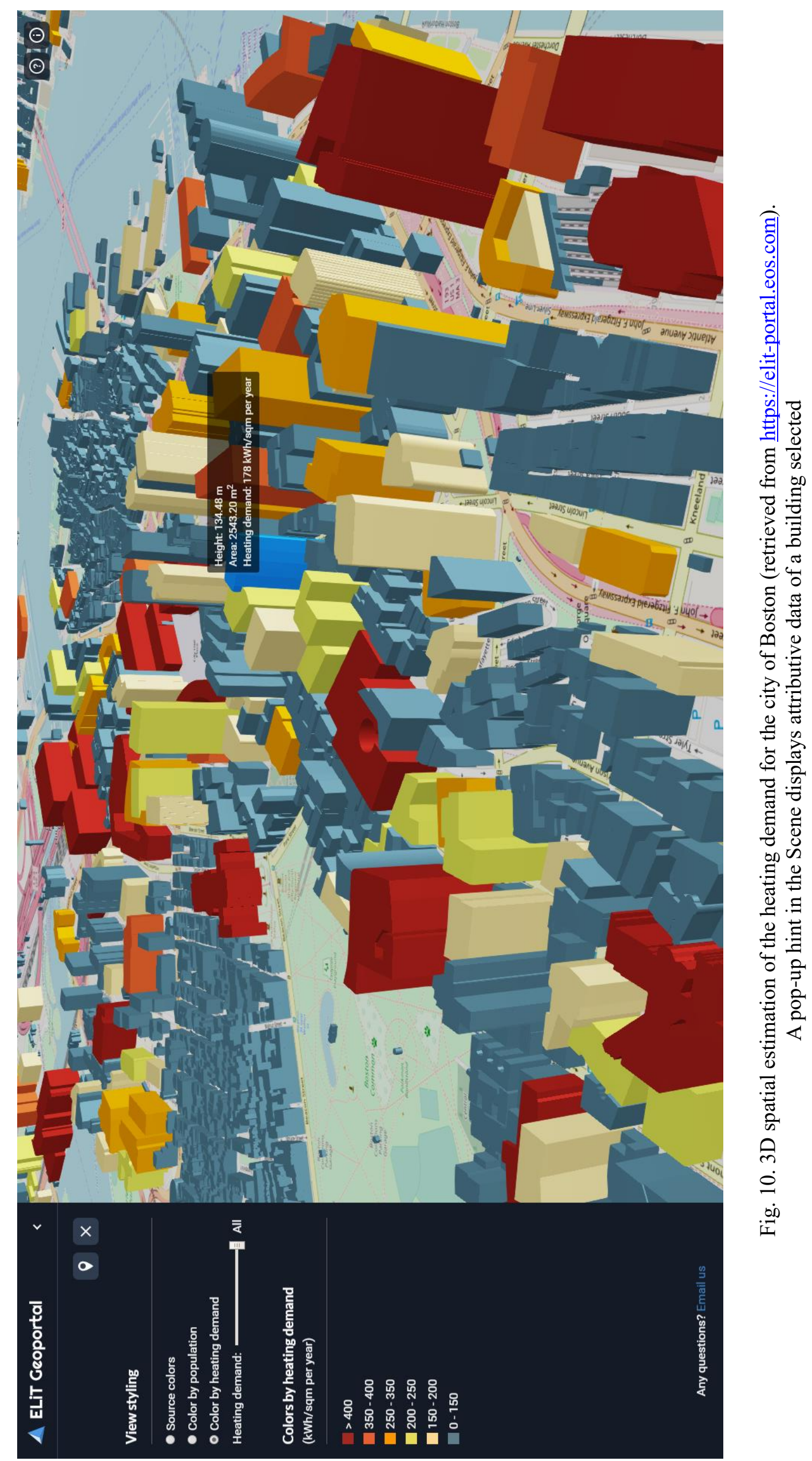


A number of use-cases are being planned to be implemented on the EGP as the nearest future works, and there are only few of them as follows. Population estimation with building geometries: A simplified EGP-building model with bounded attributive information according to a number of flows is a key factor of a resident number in a building. A set of these models within an outlined neighborhood produces a population estimation for an AOI. Energy demand for heating and cooling can be estimated on the similar to the previous use-case approach. Building geometries serve as an interface for processing building energy demand (Fig. 10). Visibility analysis may allow a Geoportal visitor determine, which areas in urban environment are visually connected. With the $E G P$ it will be possible to provide simple computation that shows those urban environment parcels, that are visible from an observer's point, and those ones, which are invisible. What is more, this viewshed analysis results show by how much the feature height must be changed for the feature to become just visible.

Both these EGP use-cases and other possible ones can hardly be overvalued after moving most of ELiT Server functionalities to the Geoportal, while we get a chance to complete urban modelling procedures not only in a block, and district scales, but in a whole city are as well up to a huge megapolis territory (refer to Fig. 8 as to an example).

\section{References}

1. Esch T. Delineation of urban footprints from TerraSAR-X data by analyzing speckle characteristics and intensity information [Text] / T. Esch T., M. Thiel, A. Schenk [and other] // IEEE Transactions on Geoscience and Remote Sensing. - 2010. - Vol. 48. - No. 2. - P. 905-916.

2. Esch T. The Global Urban Footprint [Text] / Esch T., Heldens W., Hirner A. // Urban Remote Sensing / Q. Weng, D. Quattrochi, P.E. Gamba-CRC Press, 2018-P. 34-43.

3. Kostrikov S. Geoinformation approach to the urban geographic system research (case studies of Kharkiv region) [Text] / S. Kostrikov, L. Niemets, K. Sehida [and other] // Вісник Харківського національного університету імені В. Н. Каразіна, серія "Геологія. Географія. Екологія". - Вип. 49. - Х.: ХНУ, 2018. - C. 107-121. DOI: https://doi.org/10.26565/2410-7360-2018-49-09

4. Kostrikov S. Urban remote sensing with LIDAR for the Smart City concept implementation [Text] / S. Kostrikov // Вісник Харківського начіонального університету імені В. Н. Каразіна, серія "Геологія. Географія. Екологія". - Bun. 50. - X.: XHY, 2019. - C. 101-124. DOI: https://doi.org/10.26565/2410-7360-2019-50-08

5. Biljecki F. Applications of 3D City Models: State of the Art Review [Text] / F. Biljecki, J. Stoter, H. Ledoux [and other] // ISPRS International Journal of Geo-Information. - 2015. - Vol. 4. - P. 2842-2889.

6. Day A. From map to model: the development of an urban information SYSTEM / A. Day // Design Studies. - 1994. Vol. 15. - P. 366-384.

7. Batty M. The new geography of the third dimension [Text] / M. Batty // Environment and Planning B: Planning and Design. - 2000. - Vol. 27. - P.483-487.

8. Kostrikov S. Attributive data for GIS and definition of the fluvial topography morphological-morphometric characteristics [Text] / S. Kostrikov // GEOINFORMATIKA - Journal of EGIS Ukrainian division. - 2004. - No 4. - P. 70-77.

9. ITC Educational Textbook Series. Principles of Geographic Information Systems / O. Huisman, R. A. de By (editors.). - Enschede, The Netherlands, 2009. - 540 p.

10. Brewer C.A. Designing Better Maps: A Guide for GIS Users [Text] / C.A. Brewer. - ESRI Press, $2015 .-400$ p.

11. Weng $Q$. Remote sensing for urbanization in tropical and subtropical regions - Why and what matters? [Text] / Q. Weng // Remote Sensing of Impervious Surfaces in Tropical and Subtropical Areas. Boca Raton / Zhang, H., Lin, H. Zhang, Y., Q. Weng (Editors). - FL: CRC Press/Taylor \& Francis, 2015. - P. 17-22.

12. Ban Y., Gong P., Giri C. Global land cover mapping using Earth observation satellite data: Recent progresses and challenges [Text] / Y. Ban, P. Gong, C. Giri // ISPRS Journal of Photogrammetry and Remote Sensing. - 2015. Vol. 103. - P. 1-6.

13. Esch T. Breaking new ground in mapping human settlements from space. The Global Urban Footprint [Text] / Esch T. Heldens W., Hirner A. [and other] // ISPRS Journal of Photogrammetry and Remote Sensing. - 2017. - Vol. 134, 30-42.

14. Potere D. Mapping urban areas on a global scale: Which of the eight maps now available is more accurate? [Text] / D. Potere, A. Schneider, S. Angel [and other] // International Journal of Remote Sensing. - 2009. - Vol. 30. - No 24. - P. 6531-6558.

15. Schneider A. Mapping global urban areas using MODIS 500-m data: New methods and datasets based on 'urban ecoregions [Text] / A. Schneider, M. Friedl, D. Potere // Remote Sensing of Environment. - 2010. - Vol. 114. - No 8. - P. 1733-1746.

16. Zhou Q. A preliminary review on three-dimensional city model [Text] / Q. Zhou, W. Zhang // Geo-Spatial Information Science. - 2004. - Vol. 7. - 79-88.

17. Ellul C. Deriving a Generic Topological Data Structure for 3D Data [Text] / C. Ellul, M. Haklay, T. Bevan // Proceedings of GISRUK. 13 th Annual Conference. - 2005. - P. 137-142.

18. Ellul C. Requirements for Topology in 3D GIS [Text] / C. Ellul, M. Haklay // Transactions in GIS. - Wiley Online Library. - 2006. - Vol. 10. - No. 2. - P. 157-175. 
19. Brenner C. Towards fully automatic generation of city models [Text] / C. Brenner // ISPRS Archives. Amsterdam. 2000. - Vol. XXXIII. - P. 1-8.

20. Brenner C. Building reconstruction from images and laser scanning [Text] / C. Brenner // International Journal of Applied Earth Observation and Geoinformation. - 2005. - Vol. 6. - No 3. - P. 187-198.

21. Zhang L. Modeling and analyzing 3D complex building interiors for effective evacuation simulations [Text] / L. Zhang, Y. Wang, H. Shi // Fire Safety Journal. - 2012. - Vol. 53. - P. 1-12.

22. Katsianis M. A 3D digital workflow for archaeological intra-site research using GIS [Text] / M. Katsianis, S. Tsipidis, K. Kotsakis [and other] // Journal of Archaeological Science. - 2008. - Vol. 35. - P. 655-667.

23. Groger G. How to achieve consistency for 3D city models [Text] / G. Groger, L. Plumer // Geoinformatica. - 2011. - Vol. 15. - P. 137-165.

24. Kostrikov S. Three key EOS LiDAR Tool functionalities for Urban Studies [Text] / S. Kostrikov, R. Pudlo, A. Kostrikova // The Full Paper Proceeding of ACRS'2018, Kuala Lumpur, Malaysia, technical session: LiDAR Data Processing. - 2018. - Vol. 3. - P. 1676-1685.

25. Kostrikov S. Studying of urban features by the multifunctional approach to LiDAR data processing /S. Kostrikov, R. Pudlo, A. Kostrikova, D. Bubnov // IEEE Xplore Digital Library, 2019. - Electronic ISSN: 2642-9535. - Available at: https://ieeexplore.ieee.org/document/8809063

26. Weidner U. Towards automatic building extraction from high-resolution digital elevation models [Text] / U. Weidner, W. Förstner // ISPRS Journal of Photogrammetry and Remote Sensing. - 1995. - Vol. 50. - P. 38-49.

27. Baltsavias E.P. Use of DTMs [Text] / E.P. Baltsavias, S. Mason, D. Stallmann // DSMs and orthoimages to support building extraction, Workshop on AEMOASI, Basel. - 1995. - P. 199-210.

28. Pesaresi M. A new approach for the morphological segmentation of high-resolution satellite imagery [Text] / M. Pesaresi, J. Benediktsson // IEEE Transaction on Geosciences and Remote Sensing. - 2001. - Vol. 39. - P. 309-320.

29. Awrangjeb M. Automatic segmentation of raw LIDAR data for extraction of building roofs [Text] / M. Awrangjeb, C. Fraser // Remote Sensing. - 2014. - Vol. 6. - P. 3716-3751.

30. Liu C. Automatic buildings extraction from LiDAR data in urban area by neural oscillator network of visual cortex [Text] / C. Liu, B. Shi, X. Yang [and other] // IEEE Journal of Selected Topics in Applied Earth Observations and Remote Sensing. - 2013. - Vol. 6. - P. 2008-2019.

31. Dong P. LiDAR Remote Sensing and Applications [Text] / P. Dong, Q. Chen (Editors). - Boca Raton: CRC Press, 2018. $-246 p$.

32. Shan J. Urban dem generation from raw LiDAR data: a labeling algorithm and its performance [Text] / J. Shan, A. Sampath // Photogrammetric Engineering and Remote Sensing. - 2009. - Vol. 75. - P 427-442.

33. Sampath A., Shan J. Segmentation and reconstruction of polyhedral building roofs from aerial LIDAR point clouds [Text] / A. Sampath, J. Shan // IEEE Transactions of Geoscience \& Remote Sensing - 2010. - Vol. 3. - P. $1554-1567$.

34. Sun S. Complex Building Roof Detection and Strict Description From LIDAR Data and Orthorectified Aerial Imagery [Text] / S. Sun., C. Salvaggio // IEEE International Geoscience and Remote Sensing Symposium. - 2012. - P. 54665469.

35. Belkhouche M.Y. Iterative TIN-based automatic filtering of sparse LiDAR data [Text] / M.Y. Belkhouche, B. Buckles // Remote Sensing Letters. - 2012. - Vol. 2. - No 3. - P. 231-240.

36. Chen D. Urban building roof segmentation from airborne LiDAR point clouds [Text] / D. Chen, L. Zhang, R. Liu // International Journal of Remote Sensing. - 2012. - Vol. 33. - P. 6497-6515.

37. Wang R. 3D building modeling using images and LiDAR: a review [Text] /R. Wang // International Journal of Image and Data Fusion. - 2013. - Vol. 4. - No 4. - P. 273-292.

38. Perera G.S.N. Cycle graph analysis for 3D roof structure modelling: Concepts and performance [Text] / G.S.N. Perera, H.G. Maas // ISPRS Journal of Photogrammetry and Remote Sensing. - 2014. - Vol. 93. - P. $213-226$.

39. Shan J., Toth Ch. Topographic Laser Ranging and Scanning Pronciple and Processing. $2^{\text {nd }}$ Edition / J. Shan, Ch. Toth (Editors). - London-New York: CRC Press, 2018. - 826 p.

40. Gruen A. TOBAGO-A semi-automated approach for the generation of 3-D building models [Text] / A. Gruen // ISPRS Journal of Photogrammetry and Remote Sensing. - 1998. - Vol. 53. - P. 108-118.

41. Haala N. Extraction of buildings and trees in urban environments [Text] / N. Haala, C. Brenner // ISPRS Journal of Photogrammetry and Remote Sensing. - 1999. - Vol. 54. - P. 130-137.

42. Maas H.-G. Two algorithms for extracting building models from raw laser altimetry data [Text] / H.-G. Maas, G. Vosselman // ISPRS Journal of Photogrammetry and Remote Sensing. - 1999. - Vol. 54. - P. 153-163.

43. Stilla U. Potential and limits of InSAR data for building reconstruction in built-up areas [Text] / U. Stilla, U. Soerge, U. Thoennessen // ISPRS Journal of Photogrammetry and Remote Sensing. - 2003. - Vol. 58. - P. 113-123.

44. Suveg, I., and Vosselman, G., 2004. Reconstruction of Vol.3D building models from aerial images and maps [Text] / I. Suveg, G. Vosselman // ISPRS Journal of Photogrammetry and Remote Sensing. - 2004. - Vol. 58. - P. $202-224$.

45. Alexander $C$. Integrating building footprints and LiDAR elevation data to classify roof structures and visualise buildings [Text] / C. Alexander, S. Smith-Voysey, C. Jarvis [and other] // Computers, Environment and Urban Systems. - 2009. - Vol. 33. - P. 285-292.

46. Pu S. Knowledge based reconstruction of building models from terrestrial laser scanning data [Text] / S. Pu, G. Vosselman // ISPRS Journal of Photogrammetry and Remote Sensing. - 2009. - Vol. 64. - P. 575-584. 
47. Orthuber E. 3D building reconstruction from Lidar point clouds by adaptive dual contouring [Text] / E. Orthuber, J. Avbelj // ISPRS Annals of the Photogrammetry, Remote Sensing and Spatial Information Sciences. - 2015. - Volume II-3/W4. - PIA15+HRIGI15-Joint ISPRS conference 2015, 25-27 March, 2015, Munich, Germany.

48. Hu Y. Automated Extraction of DTM, roads, and buildings using Airborne lidar [Text] / Y. Hu. - UCGE Reports. Number 20187. - University of Calgary, 2007. - 227 p.

49. Aijazi A.K. Automatic detection and feature estimation of windows in $3 D$ urban point clouds exploiting façade symmetry and temporal correspondences [text] / A.K. Aijazi, P. Checchin, L. Trassoudaine // International Journal of Remote Sensing // 2014. - Vol. 35. - P. 7726-7748.

50. Arachchige N.H., Perera S.N., Maas H.G. Automatic processing of mobile laser scanner point clouds for building facade detection [Text] / A.N. Arachchige, S.N. Perera, H.G. Maas // ISPRS International Archive of Photogrammetry and Remote Sensing in Spatial Information Science. - 2012. - Vol. XXXIX-B5. - P. 187-192.

51. Yang B. Hierarchical extraction of urban objects from mobile laser scanning data [Text] / B. Yang, Z. Dong, G. Zhao [and other] // ISPRS Journal of Photogrammetry and Remote Sensing. - 2015. - Vol. 99. - P. 45-57.

52. Brinkman R. LiDAR and photogrammetric mapping [Text] / R. Brinkman, C. O'Neill // The Military Engineer. 2000. - No. 5. - P. 56-57.

53. Hodgson M. Accuracy of airborne lidar-derived elevation: Empirical assessment and error budget [Text] / M. Hodgson, P. Bresnahan // Photogrammetric Engineering and Remote Sensing. - 2004. - Vol. 70. - P. 331-339.

54. Xiao Y. Building segmentation and modeling from airborne LiDAR data [Text] / Y. Xiao, C. Wang, J. Li [and other] // International Journal of Digital Earth. - 2014. - Vol. 8. - P. 694-709.

55. Zhang K., Whitman D. Comparison of three algorithms for filtering airborne LiDAR data [Text] / K. Zhang, D. Whitman // Photogrammetric Engineering and Remote Sensing. - 2005. - Vol. 71. - P. 313-324.

56. Umasuthan U. Outlier removal and discontinuity preserving smoothing of range data [Text] / U. Umasuthan, A.M. Wallace // IEEE Proceedings on Visual Imaging \& Signal Processing. - 1996. - Vol. 143. - No 3. - P. 191-200.

57. Haala N. An update on automatic 3D building reconstruction [Text] / N. Haala, M. Kada // ISPRS Journal of Photogrammetry and Remote Sensing. - 2010. - Vol. 65. - No 6. - P. 570-580.

58. Vosselman G. 3D building model reconstruction from point clouds and ground plans [Text] / G. Vosselman, S. Dijkman // International Archive of Photogrammetry and Remote Sensing. - 2001. - Vol. XXXIV-3/W4. - P. 37-43.

59. Oda K. Automatic building extraction and 3-D city modeling from lidar data based on Hough transformation [Text] / K. Oda, T. Takano, T. Doihara // International Archive of Photogrammetry and Remote Sensing. - 2004. - Vol. $X X X V$, part B3.

60. Evans J.S. A multiscale curvature algorithm for classifying discrete return LiDAR in forested environments [Text] / J.S. Evans, A.T. Hudak // IEEE Transactions of Geoscience and Remote Sensing. - 2008. - Vol. 46. - P. 987-997.

61. Song J.H. Assessing the possibility of land-cover classification using lidar intensity data [Text] / J.H. Song, S.H. Han., K. Yu [and other] // IAPRS. - 2002. - Vol. 34. - P. 41-47.

62. Kwak E. Automatic representation and reconstruction of DBM from LiDAR data using recursive minimum bounding rectangle [Text] / E. Kwak, A. Habib // ISPRS Journal of Photogrammetry and Remote Sensing. - 2014. - Vol. 93. No 7. - P. 171-191.

63. Lee H.S. DTM extraction of LiDAR returns via adaptive processing [Text] / H.S. Lee, N.H. Younan // IEEE Transactions of Geoscience Remote Sensing. - 2003. - Vol. 41. - P. 2063-2069.

64. Sithole G. Experimental comparison of filter algorithms for bare-earth extraction from airborne laser scanning point clouds [Text] / G. Sithole, G. Vosselman // Photogrammetric Engineering and Remote Sensing. - 2004. - Vol. 59. 85-101.

65. Awrangjeb M. Automatic detection of residential building using LiDAR data and multispectral imagery [Text] / M. Awrangjeb, M. Ravanbakhsh, C.S. Fraser // ISPRS Journal of Photogrammetry and Remote Sensing. - 2011. - Vol. 66. - No 6. - P. 668-679.

66. Alharthy A. Heuristic filtering and 3D feature extraction from LiDAR data [Text] / A. Alharthy, J. Bethel // International Archives on Photogrammetry and Remote Sensing. - 2002. - Vol. 34 (3A). - P. 29-34.

67. Rottensteiner $F$. Using the Dempster-Shafer method for the fusion of LiDAR data and multispectral images for building detection [Text] / F. Rottensteiner // Information Fusion. - 2005. - Vol. 6 (4). - P. 283-300.

68. Wang J. Segmentation of LiDAR point clouds for building extraction [Text] / J. Wang, J. Shan // Proceedings of American Society for Photogrammetry and Remote Sensing Annual Conference, Baltimore, MD. - 2009. - P. 9-13.

69. Sohn G. Using binary space partitioning tree for reconstructing polyhedral building models from airborne LIDAR data [Text] / G. Sohn, X. Huang, V. Tao // Photogrammetric Engineering and Remote Sensing. - 2008. - Vol. 74. P. 1425-1438.

70. Charles R.Q. PointNet: Deep Learning on Point Sets for 3D Classification and Segmentation / R.Q. Charles. - 2017. - Available at: http://stanford.edu/ rqi/pointnet/

71. Schiewe J. Integration of multi-sensor data for landscape modeling using a region-based approach [Text] / J. Schiewe // ISPRS JPRS. - 2003. - Vol. 57. - P. 371-379.

72. Dorninger P. A comprehensive automated 3D approach for building extraction, reconstruction, and regularization from airborne laser scanning point clouds [Text] / P. Dorninger, N. Pfeifer // Sensors - 2008. - Vol. 8. - No 11. - P. 7323-7343.

73. Zhang C. Knowledge-based image analysis for 3D road reconstruction [Text] / C. Zhang, E. Baltsavias, A. Gruen // Asian Journal of Geoinformatics. - 2001. - Vol. 1. - No. 4. - P. 3-14. 
74. Wang Z. Building extraction and reconstruction from lidar data [Text] / Z. Wang, T. Schenk // IAPRS. - 2000. - 1722 July, Amsterdam. - Vol. 33. - Part B3. - P. 958-964.

75. Rottensteiner D.F., Briese C. A new method for building extraction in urban areas from high-resolution lidar data [Text] / D.F. Rottensteiner, C. Briese // IAPRS, 9-13 September, Graz, Austria. - 2002. - Vol. 34. - Part 3A/B. - P. 295-301.

76. Vestri C. Using robust methods for automatic extraction of buildings [Text] / C. Vestri, F. Devernay // CVPR. - 2001. - Vol. 1. - P. 133-138.

77. Xu L. On-the-fly extraction of polyhedral buildings from airborne LiDAR data [Text] / L. Xu, D. Kong, X. Li // IEEE Geoscience and Remote Sensing Letters. - 2014. - Vol. 11. - No. 11. - P. 1946-1950.

78. Estivill-Castro V. Why so many clustering algorithms: a position paper [Text] / V. Estivill-Castro // ACM SIGKDD Explorations Newsletter. - 2002. - Vol. 4. - No. 1. - P. 65-75.

79. Sampath A. Building boundary tracing and regularization from airborne LiDAR point clouds / A. Sampath, J. Shan // Photogrammetric Engineering \& Remote Sensing. - 2007. - Vol. 73. - No. 7. - P. 805-812.

80. Lari Z. An adaptive approach for the segmentation and extraction of planar and linear/cylindrical features from laser scanning data [Text] / Z. Lari, A. Habib // ISPRS Journal of Photogrammetry and Remote Sensing. - 2014. Vol. 93. - No. 7. - P. 192-212.

81. Костріков C. Веб-застосування ELiT - програмне забезпечення для моделювання $і$ аналізу міського середовища [Текст] / С. Костріков, Д. Бубнов, А. Кострікова, Р. Пудло // Збірник матеріалів конференції «ГІСФорум»-2018». - Харків, $2018-$ С. 56-59.

82. Костріков С.В. Дослідження міського середовища через його відтворення за допомогою обробки лідарданих [Текст] / С.В. Костріков, В.В. Васильєв, Р.А. Пудло, Д.С. Бубнов // Матеріали міжнародної науковопрактичної конферениії «РЕГІОН-2019: Стратегія оптимального розвитку» - Харків, 2019. - С. 34-37.

83. Костріков C.B. Програмне забезпечення ГIC для LiDAR-технології дистанційного зондування в цілях аналізу урбогеосистем [Текст] / С.В. Костріков, Д.Л. Кулаков, К.Ю. Сегіда // Проблеми безперервної географічної освіти і картографії-ГІС-форум'14. Збірник наукових праџь - 2014. - Bun. 19. - C. 45-52.

84. Teo T.-A. Lidar-based change detection and change type determination in urban areas [Text] / T.A. Teo, T.Y. Shi // International Journal of Remote Sensing. - 2012. - Vol. 34. - P. 968-981.

85. Zhang K. Automatic construction of building footprints from airborne LiDAR data // IEEE Transactions on Geoscience and Remote Sensing [Text] / K. Zhang, J. Yan, S.C. Chen. - 2006. - Vol. 44. - No. 9. - P. 2523-2533.

86. Stilla U. Reconstruction of building models from maps and laser altimeter data [Text] / U. Stilla, K. Jurkiewicz // P. Agouris, A. Stefanidis (Editors). Integrated Spatial Databases: Digital Images and GIS. - Springer, Berlin, 1999. P. 34-46.

87. Shewchuk J. Delaunay refinement algorithms for triangular mesh generation [Text] / J. Shewchuk // Computing Geometry. - 2014. - Vol. 47. - P. 741-778.

88. Shan J., Sampath A. Building extraction from LiDAR point clouds based on clustering techniques [Text] / J. Shan, A. Sampath // Topographic Laser Ranging and Scanning: Principles and Processing / J. Shan, C. Toth (Editors). - Boca Raton, FL: CRC Press. - Ch. 15. - 2008. - P. 423-446.

89. Sampath A. Building roof segmentation and reconstruction from lidar point clouds using clustering techniques [Text] / A. Sampath, J. Shan // International Archive of Photogrammetry and Remote Sensing. - 2008. - Vol. XXXVII, Part B3a. - P. 279-284.

90. Tarsha-Kurdi F. Extended RANSAC algorithm for automatic detection of building roof planes from LIDAR data [Text] / F. Tarsha-Kurdi, T. Landes, P., Grussenmeyer // Photogrammetric Journal of Finland. - 2008. - Vol. 21. No 1. - P. 97-109.

91. Sun S. Aerial 3D building detection and modeling from airborne LiDAR point clouds [Text] / S. Sun., C. Salvaggio // IEEE Journal of Selected Topics in Applied Earth Observations and Remote Sensing. - 2013. - Vol. 6. - No. 3. P. 1440-1449.

92. Fan H. Segmentation of Sloped Roofs from Airborne LiDAR Point Clouds Using Ridge-Based Hierarchical Decomposition [Text] / H. Fan, W. Yao, Q. Fu // Remote Sensing. - 2014. - Vol. 6. - P. 3284-3301.

93. Tse R. Using the Delaunay Triangulation/ Voronoi Diagram to extract Building Information from Raw LIDAR Data [Text] / R. Tse, Ch. Gold, D. Kidner // 4th International Symposium on Voronoi Diagrams in Science and Engineering (ISVD 2007). - IEEE Xplore Digital Library, 2007. - Print ISBN: 0-7695-2869-4.

94. Tse, R. Building reconstruction using LIDAR data [Text] / R. Tse, M. Dakowicz, C.M. Gold [and other] // Proceedings 4th ISPRS workshop on dynamic and multi-dimensional GIS. - Pontypridd, Wales, UK. - 2005. - P. $156-161$.

95. Nan L. Template assembly for detailed urban reconstruction [Text] / L. Nan, C. Jiang, B. Ghanem [and other] // Computer Graphics Forum. - 2015. - Vol. 34. - P. 217-228.

96. Nan L., Wonka P. Polyfit: Polygonal surface reconstruction from point clouds / L. Nan, P. Wonka // Proceedings International Conference on Computer Vision. - 2017. - Available at: http://openaccess.thecvf.com/content_ICCV_ 2017/papers/Nan_PolyFit_Polygonal_Surface_ICCV_2017_paper.pdf

97. Tait M.G. Implementing geoportals: applications of distributed GIS [Text] / M.G. Tait // Computers, Environment and Urban Systems. - 2005. - Vol. 29. - Issue 1. - P. 33-47.

98. Beaumont P. Geographic information portals - a UK perspective [Text] / P. Beaumont, P.A. Longley, D.J. Maguire // Computers, Environment and Urban Systems. - 2005. - Vol. 29. - Issue 1. - P. 49-69.

Authors Contribution: All authors have contributed equally to this work. 
UDC 711.433: 004.9+004.451+911.3

Sergiy Vasylovych Kostrikov,

Doctor of Sciences (Geography), Professor, Department of Human Geography and Regional Studies, School of Geology, Geography, Recreation and Tourism, V. N. Karazin Kharkiv National University,

4 Svobody Sq., Kharkiv, 61022, Ukraine;

e-mail: sergiy.kostrikov@gmail.com, https://orcid.org/0000-0002-4236-8474;

Dmytro Yevgenovych Bubnov,

Scientist and Senior Programmer, EOS Data Analitics Ukraine, LLC,

31 Alchevskyh St., Kharkiv, 61002, Ukraine,

e-mail: dmitriy.bubnov@eosda.com, https://orcid.org/0000-0002-2851-8659;

Rostyslav Anatoliyovych Pudlo,

R\&D Team Leader, EOS Data Analitics Ukraine, LLC,

e-mail: rostyslav.pudlo@eosda.com, https://orcid.org/0000-0002-3018-2074

\section{URBAN ENVIRONMENT 3D STUDIES BY AUTOMATED FEATURE EXTRACTION FROM LiDAR POINT CLOUDS}

Research problem introduction. Both a number of necessities that require the novel technological introductions in urban studies and the challengers corresponding to these introductions have been outlined with the emphasis on the urban remote sensing tools. The research goal of this text is to outline the authors' original contribution to the algorithmic content of the automated feature extraction upon the urban environment modeling, as well as to represent the original web-software for urban studies.

AFE methods in the building detection, extraction and 3D reconstruction within the LiDAR pipeline: a thematic overview. The overall AFE algorithmic approach has been summarized proceeding from an extensional literature review due to the feature extraction from raw lidar data. A sample of the composite model of an urban feature extracted, the overall AFE algorithmic flowchart, and few MSL processed results have been visualized. Feature detection, classification, segmentation and reconstruction have been presented as constituents of the united LiDAR pipeline.

EOS LiDAR Tool (ELiT) and our key original algorithmic approaches to the AFE issues. The websoftware has been developed on the base of the outlined multifunctional research approach. This software has several basic functionalities within the distributed information system: building extraction, building extraction in rural areas, change detection, and digital elevation model generation. Two basic algorithmic approaches implemented in the software have been explained in details: High Polyhedral Modeling provided by the Building Extraction tool, and Low Polyhedral Modeling provided by the Building Extraction Rural Area tool. The extensive usage of the Voronoi diagram for cluster adjacency on the finalizing modeling stage has been provided as our original update of the existing LPM methodology: its applying for the roof cluster adjacency determination and for separation of coplanar clusters, applying limited diagram for avoiding side effects of adjacency determination, its applying for the awning / overhand identification.

ELiT Geoportal. The EGP has been depicted as a type of web portal used to find, access, and process LiDAR geospatial both primary, and derivative information, as well as to provide the associated geographic services (display, editing, analysis, etc.) via the Internet. The key characteristics of our Geoportal have been listed as well as some illustrations provided for the uploaded projects.

Conclusion and future works. The automated feature extraction from lidar data technique has been presented with the authors' updates as a highly promising solution for the multicomponent simulation of urban environment, that can be used for different applications for cities. The use-cases for the EGP have been outlined as hot issues: Population estimation with building geometries; Energy demand for heating and cooling; Visibility analysis in urban environment.

Keywords: LiDAR, lidar data, urban environment, AFE, building model, web-GIS-application, geoportal.

\section{References}

1. Esch T., Thiel, M., Schenk, A. [and other] (2010). Delineation of urban footprints from TerraSAR-X data by analyzing speckle characteristics and intensity information. IEEE Transactions on Geoscience and Remote Sensing, 48(2), 905-916.

2. Esch, T., Heldens, W., Hirner, A. (2018). The Global Urban Footprint. Urban Remote Sensing. CRC Press, 34-43.

3. Kostrikov, S., Niemets, L., Sehida, K. [and other]. (2018) Geoinformation approach to the urban geographic system research (case studies of Kharkiv region). Visnyk of V.N. Karazin Kharkiv National University. Series "Geology. Geography. Ecology", 49, 107-121. DOI: https://doi.org/10.26565/2410-7360-2018-49-09 
4. Kostrikov S. (2019) Urban remote sensing with LIDAR for the Smart City concept implementation. Visnyk of V.N. Karazin Kharkiv National University. Series in Geology, Geography, and Ecology, 50, 101-124. DOI: https://doi.org/10.26565/2410-7360-2019-50-08

5. Biljecki, F. Stoter, J., Ledoux, H. [and other]. (2015). Applications of 3D City Models: State of the Art Review. ISPRS International Journal of Geo-Information, 4, 2842-2889.

6. Day, A. (1994). From map to model. Design Studies, 15, 366-384.

7. Batty, M. (2000). The new geography of the third dimension. Environment and Planning B: Planning and Design, 27, 483-487.

8. Kostrikov, S. (2004). Attributive data for GIS and definition of the fluvial topography morphological-morphometric characteristics. GEOINFORMATIKA. Journal of EGIS Ukrainian division, 4, 70-77.

9. Huisman, O., de By, R.A. (editors.). (2009). ITC Educational Textbook Series. Principles of Geographic Information Systems. Enschede, The Netherlands, 540.

10. Brewer, C.A. (2015). Designing Better Maps: A Guide for GIS Users. ESRI Press, 400.

11. Weng, Q. (2015). Remote sensing for urbanization in tropical and subtropical regions - Why and what matters? Remote Sensing of Impervious Surfaces in Tropical and Subtropical Areas. Boca Raton. Zhang, H., Lin, H. Zhang, Y., Q. Weng (Editors). FL: CRC Press/Taylor \& Francis, 17-22.

12. Ban, Y., Gong, P., Giri, C. (2015). Global land cover mapping using Earth observation satellite data: Recent progresses and challenges. ISPRS Journal of Photogrammetry and Remote Sensing, 103, 1-6.

13. Esch, T. (2017). Breaking new ground in mapping human settlements from space. The Global Urban Footprint. ISPRS Journal of Photogrammetry and Remote Sensing, 134, 30-42.

14. Potere, D., Schneider, A., Angel, S. (2009). Mapping urban areas on a global scale: Which of the eight maps now available is more accurate? International Journal of Remote Sensing, 30, 6531-6558.

15. Schneider, A. (2010). Mapping global urban areas using MODIS 500-m data: New methods and datasets based on 'urban ecoregions. Remote Sensing of Environment, 114 (8), 1733-1746.

16. Zhou, Q., Zhang, W. (2004). A preliminary review on three-dimensional city model. Geo-Spatial Information Science, 7, 79-88.

17. Ellul, C., Haklay, M., Bevan, T. [and other]. (2005). Deriving a Generic Topological Data Structure for 3D Data. Proceedings of GISRUK. $13^{\text {th }}$ Annual Conference, 137-142.

18. Ellul, C., Haklay, M. (2006). Requirements for Topology in 3D GIS. Transactions in GIS. Wiley Online Library, 10 (2), 157-175.

19. Brenner, C. (2000). Towards fully automatic generation of city models. ISPRS Archives. Amsterdam, XXXIII, $1-8$.

20. Brenner, C. (2005). Building reconstruction from images and laser scanning. International Journal of Applied Earth Observation and Geoinformation, 6 (3), 187-198.

21. L. Zhang, L., Wang, Y., Shi Zhang, H. (2012). Modeling and analyzing 3D complex building interiors for effective evacuation simulations. Fire Safety Journal, 53, 1-12.

22. Katsianis, M.; Tsipidis, S.; Kotsakis, K. [and other]. (2008). A 3D digital workflow for archaeological intra-site research using GIS. Journal of Archaeological Science, 35, 655-667.

23. Groger, G., Plumer, L. (2011). How to achieve consistency for 3D city models. Geoinformatica, 15, 137-165.

24. Kostrikov, S. Pudlo, R. Kostrikova, A. (2018). Three Key EOS LiDAR Tool Functionalities for Urban Studies. Full Paper Proceeding of ACRO'2018, Kuala Lumpur, Malaysia. Technical Session: LiDAR Data Processing, 3, 1676 1685.

25. Kostrikov, S., Pudlo, R., Kostrikova, A. [and other]. (2019). Studying of urban features by the multifunctional approach to LiDAR data processing. IEEE Xplore Digital Library. Electronic ISSN: 2642-9535. Available at: https://ieeexplore.ieee.org/document/8809063

26. Weidner, U., Förstner, W. (1995). Towards automatic building extraction from high-resolution digital elevation models. ISPRS Journal of Photogrammetry and Remote Sensing, 50, 38-49.

27. Baltsavias, E.P., Mason, S., Stallmann, D. (1995). Use of DTMs. DSMs and orthoimages to support building extraction. Workshop on AEMOASI, Basel, 199-210.

28. Pesaresi, M., Benediktsson, J. (2001). A new approach for the morphological segmentation of high-resolution satellite imagery. IEEE Transaction on Geosciences and Remote Sensing, 39, 309-320.

29. Awrangjeb, M., Fraser, C. (2014). Automatic segmentation of raw LIDAR data for extraction of building roofs. Remote Sensing, 6, 3716-3751.

30. Liu, C. Shi, B., Yang, X. [and other]. (2013). Automatic buildings extraction from LiDAR data in urban area by neural oscillator network of visual cortex. IEEE Journal of Selected Topics in Applied Earth Observations and Remote Sensing, 6, 2008-2019.

31. Dong P., Chen, Q. (Editors). (2018). LiDAR Remote Sensing and Applications. Boca Raton: CRC Press, 246.

32. Shan, J., Sampath, A. (2009). Urban dem generation from raw LiDAR data: a labeling algorithm and its performance. Photogrammetric Engineering and Remote Sensing, 75, 427-442.

33. Sampath, A., Shan, J. (2010). Segmentation and reconstruction of polyhedral building roofs from aerial LIDAR point clouds. IEEE Transactions of Geoscience \& Remote Sensing, 3, 1554-1567.

34. Sun, S., Salvaggio, C. (2012). Complex Building Roof Detection and Strict Description From LIDAR Data and Orthorectified Aerial Imagery. IEEE International Geoscience and Remote Sensing Symposium, 5466 - 5469.

35. Belkhouche, M.Y., Buckles, B. (2012). Iterative TIN-based automatic filtering of sparse LiDAR data. Remote Sensing Letters, 2(3), 231-240.

36. Chen, D. Zhang, L., Liu, R. (2012). Urban building roof segmentation from airborne LiDAR point clouds. International Journal of Remote Sensing, 33, 6497-6515. 
37. Wang, R. (2013). 3D building modeling using images and LiDAR: a review. International Journal of Image and Data Fusion, 4(4), 273-292.

38. Perera, G.S.N., Maas, H.-G. (2014). Cycle graph analysis for 3D roof structure modelling: Concepts and performance. ISPRS Journal of Photogrammetry and Remote Sensing, 93, 213-226.

39. Shan, J., Toth, Ch. (Editors). (2018). Topographic Laser Ranging and Scanning Pronciple and Processing. $2^{\text {nd }}$ Edition / J. Shan, Ch. Toth (Editors). London - New York. CRC Press, 826.

40. Gruen, A. (1998). TOBAGO-A semi-automated approach for the generation of 3-D building models. ISPRS Journal of Photogrammetry and Remote Sensing, 53, 108-118.

41. Haala, N., Brenner, C. (1999). Extraction of buildings and trees in urban environments. ISPRS Journal of Photogrammetry and Remote Sensing, 54, 130-137.

42. Maas, H.-G. Vosselman, G. (1999). Two algorithms for extracting building models from raw laser altimetry data. ISPRS Journal of Photogrammetry and Remote Sensing, 54, 153-163.

43. Stilla, U., Soerge, U., Thoennessen, U. (2003). Potential and limits of InSAR data for building reconstruction in built-up areas. ISPRS Journal of Photogrammetry and Remote Sensing, 58, 113-123.

44. Suveg, I., and Vosselman, G. (2004). Reconstruction of Vol.3D building models from aerial images and maps. ISPRS Journal of Photogrammetry and Remote Sensing, 58, 202-224.

45. Alexander, C. Smith-Voysey, S. Jarvis, C. [and other]. (2009). Integrating building footprints and LiDAR elevation data to classify roof structures and visualise buildings. Computers, Environment and Urban Systems, 33, $285-292$.

46. Pu, S., Vosselman, G. (2009). Knowledge based reconstruction of building models from terrestrial laser scanning data. ISPRS Journal of Photogrammetry and Remote Sensing, 64, 575-584.

47. Orthuber, E., Avbelj, J. (2015). 3D building reconstruction from Lidar point clouds by adaptive dual contouring. ISPRS Annals of the Photogrammetry, Remote Sensing and Spatial Information Sciences, II-3/W4, PIA15+HRIGI15. Joint ISPRS conference 2015, 25-27 March, Munich, Germany.

48. Hu, Y. (2007). Automated Extraction of DTM, roads, and buildings using Airborne lidar. UCGE Reports. Number 20187. University of Calgary, 227.

49. Aijazi, A.K., Checchin, P., Trassoudaine, L. (2014). Automatic detection and feature estimation of windows in 3D urban point clouds exploiting façade symmetry and temporal correspondences // International Journal of Remote Sensing, 35, 7726-7748.

50. Arachchige, N.H., Perera, S.N., Maas, H.G. (2012). Automatic processing of mobile laser scanner point clouds for building facade detection. ISPRS International Archive of Photogrammetry and Remote Sensing in Spatial Information Science, XXXIX-B5, 187-192.

51. Yang, B., Dong, Z., Zhao, G. [and other]. (2015). Hierarchical extraction of urban objects from mobile laser scanning data. ISPRS Journal of Photogrammetry and Remote Sensing, 99, 45-57.

52. Brinkman, R., O'Neill, C. (2000). LiDAR and photogrammetric mapping. The Military Engineer, 5, 56-57.

53. Hodgson, M., Bresnahan, P. (2004). Accuracy of airborne lidar-derived elevation: Empirical assessment and error budget. Photogrammetric Engineering and Remote Sensing, 70, 331-339.

54. Xiao, Y., Wang, C. Li, J. [and other]. (2014). Building segmentation and modeling from airborne. International Journal of Digital Earth, 8, 694-709.

55. Zhang, K., Whitman, D. (2005). Comparison of three algorithms for filtering airborne LiDAR data. Photogrammetric Engineering and Remote Sensing, 71, 313-324.

56. Umasuthan, U., Wallace, A.M. (1996). Outlier removal and discontinuity preserving smoothing of range data. IEEE Proceedings on Visual Imaging \& Signal Processing, 143, 3, 191-200.

57. Haala, N., Kada, M. (2010). An update on automatic 3D building reconstruction. ISPRS Journal of Photogrammetry and Remote Sensing, 65(6), 570-580.

58. Vosselman, G., Dijkman, S. (2001). 3D building model reconstruction from point clouds and ground plans. International Archive of Photogrammetry and Remote Sensing, XXXIV-3/W4, 37-43.

59. Oda, K., Takano, T., Doihara, T. (2004). Automatic building extraction and 3-D city modeling from lidar data based on Hough transformation. International Archive of Photogrammetry and Remote Sensing, XXXV, part B3.

60. Evans, J.S., Hudak, A.T. (2008). A multiscale curvature algorithm for classifying discrete return LiDAR in forested environments. IEEE Transactions of Geoscience and Remote Sensing, 46, 987-997.

61. Song, J.H., Han, S.H., Yu, K. [and other]. (2002). Assessing the possibility of land-cover classification using lidar intensity data. IAPRS, 34, 41-47.

62. Kwak, E., Habib, A. (2014). Automatic representation and reconstruction of DBM from LiDAR data using recursive minimum bounding rectangle. ISPRS Journal of Photogrammetry and Remote Sensing, 93(7), 171-191.

63. Lee, H.S,, Younan, N.H.(2003). DTM extraction of LiDAR returns via adaptive processing. IEEE Transactions of Geoscience Remote Sensing, 41, 2063-2069.

64. Sithole, G., Vosselman, G. (2004). Experimental comparison of filter algorithms for bare-earth extraction from airborne laser scanning point clouds. Photogrammetric Engineering and Remote Sensing, 59, 85-101

65. Awrangjeb, M., Ravanbakhsh, M., Fraser, C.S. (2011). Automatic detection of residential building using LiDAR data and multispectral imagery. ISPRS Journal of Photogrammetry and Remote Sensing, 66(6), 668-679.

66. Alharthy, A., Bethel, J. (2002). Heuristic filtering and 3D feature extraction from LiDAR data. International Archives on Photogrammetry and Remote Sensing, 34 (3A), 29-34.

67. Rottensteiner, F. (2005). Using the Dempster-Shafer method for the fusion of LiDAR data and multispectral images for building detection. Information Fusion, 6 (4), 283-300.

68. Wang, J., Shan, J. (2009). Segmentation of LiDAR point clouds for building extraction. Proceedings of American Society for Photogrammetry and Remote Sensing Annual Conference, Baltimore, MD, 9-13. 
69. Sohn, G., Huang, X., Tao, V. (2008). Using binary space partitioning tree for reconstructing polyhedral building models from airborne LIDAR data. Photogrammetric Engineering and Remote Sensing, 74, 1425-1438.

70. Charles, R.Q. (2017). PointNet: Deep Learning on Point Sets for 3D Classification and Segmentation. Available at: http://stanford.edu/ rqi/pointnet/

71. Schiewe, J. (2003). Integration of multi-sensor data for landscape modeling using a region-based approach. ISPRS JPRS, 57, 371-379.

72. Dorninger, P., Pfeifer, N. (2008). A comprehensive automated 3D approach for building extraction, reconstruction, and regularization from airborne laser scanning point clouds. Sensors, 8(11), 7323-7343.

73. Zhang, C., Baltsavias, E., Gruen, A. (2001). Knowledge-based image analysis for $3 D$ road reconstruction. Asian Journal of Geoinformatics, 1(4), 3-14.

74. Wang, Z., Schenk, T. (2000). Building extraction and reconstruction from lidar data. IAPRS. 17-22 July, Amsterdam, 33, part B3, 958-964.

75. Rottensteiner, D.F., Briese, C. A new method for building extraction in urban areas from high-resolution lidar data. IAPRS, 9-13 September, Graz, Austria, 34, Part 3A/B, 295-301.

76. Vestri, C., Devernay, F. (2001). Using robust methods for automatic extraction of buildings. CVPR, 1, 133-138.

77. Xu, L. Kong, D., Li, X. (2014). On-the-fly extraction of polyhedral buildings from airborne LiDAR data. IEEE Geoscience and Remote Sensing Letters, 11(11), 1946-1950.

78. Estivill-Castro, V. (2002). Why so many clustering algorithms: a position paper. ACM SIGKDD Explorations Newsletter, 4(1), 65-75.

79. Sampath, A., Shan, J. (2007). Building boundary tracing and regularization from airborne LiDAR point clouds. Photogrammetric Engineering \& Remote Sensing, 73(7), 805-812.

80. Lari, Z., Habib, A. (2014). An adaptive approach for the segmentation and extraction of planar and linear/cylindrical features from laser scanning data. ISPRS Journal of Photogrammetry and Remote Sensing, 93(7), $192-212$.

81. Kostrikov, S., Bubnov, D., Kostrikova, A., Pudlo, R. (2018), ELiT web-application - the software for urban environment modeling and analysis. GIS-Forum-2018, 56-59.

82. Kostrikov, S., Vasiliev, V., Pudlo, R. [and other]. (2019). Urban environment research through its simulation by lidar data processing. REGION-2019: The strategy for optimal development. Kharkiv, 34-37.

83. Kostrikov S., Kulakov D., Sehida K. (2014). Programne zabezpechennya GIS dlya LiDAR-technologii dustantsijjnogo zonduvannya $v$ tsilyah analizu urbogeosystem [GIS-software for the urban geosystem analysis with LiDAR-technique]. Problemu bezperervnoi geographichnoi osvitu i kartographii. Proceedings of GIS Forum'2014, $19,45-52$.

84. Teo, T.-A., Shi, T.Y. (2012). Lidar-based change detection and change type determination in urban areas. International Journal of Remote Sensing, 34, 968-981.

85. Zhang, K., Yan, J., Chen, S.C. (2006). Automatic construction of building footprints from airborne LiDAR data. IEEE Transactions on Geoscience and Remote Sensing, 44(9), 2523-2533.

86. Stilla, U., Jurkiewicz, K. (1999). Reconstruction of building models from maps and laser altimeter data / P. Agouris, A. Stefanidis (Editors). Integrated Spatial Databases: Digital Images and GIS. Springer, Berlin, 34-46.

87. Shewchuk, J. (2014). Delaunay refinement algorithms for triangular mesh generation. Computing Geometry, 47, 741-778.

88. Shan, J., Sampath, A.. Building extraction from LiDAR point clouds based on clustering techniques. Topographic Laser Ranging and Scanning: Principles and Processing / J. Shan, C. Toth (Editors). Boca Raton, FL: CRC Press, Ch. 15, 423-446.

89. Sampath, A., Sha, J. (2008). Building roof segmentation and reconstruction from lidar point clouds using clustering techniques. International Archive of Photogrammetry and Remote Sensing, XXXVII, Part B3a, 279-284.

90. Tarsha-Kurdi, F., Landes, T., Grussenmeyer, P. (2008). Extended RANSAC algorithm for automatic detection of building roof planes from LIDAR data. Photogrammetric Journal of Finland, 21(1), 97-109.

91. Sun, S., Salvaggio, C. (2013). Aerial 3D building detection and modeling from airborne LiDAR point clouds. IEEE Journal of Selected Topics in Applied Earth Observations and Remote Sensing, 6(3), 1440-1449.

92. Fan, H., Yao, W., Fu, Q. (2014). Segmentation of Sloped Roofs from Airborne LiDAR Point Clouds Using RidgeBased Hierarchical Decomposition. Remote Sensing, 6, 3284-3301.

93. Tse, R. Gold, Ch., Kidner, D. (2007). Using the Delaunay Triangulation/ Voronoi Diagram to extract Building Information from Raw LIDAR Data. 4th International Symposium on Voronoi Diagrams in Science and Engineering (ISVD 2007). IEEE Xplore Digital Library. Print ISBN: 0-7695-2869-4.

94. Tse, R., Dakowicz, M., Gold, C.M. (2005). Building reconstruction using LIDAR data. Proceedings 4th ISPRS workshop on dynamic and multi-dimensional GIS. Pontypridd, Wales, UK, 156-161.

95. Nan, L., Jiang, C., Ghanem, B. [and other]. (2015). Template assembly for detailed urban reconstruction. Computer Graphics Forum, 34, 217-228.

96. Nan, L., Wonka, P. (2017). Polyfit: Polygonal surface reconstruction from point clouds / L. Nan, P. Wonka // Proceedings International Conference on Computer Vision. Available at: http:/lopenaccess.thecvf.com/ content_ICCV 2017/papers/Nan_PolyFit_Polygonal_Surface_ICCV 2017 paper.pdf

97. Tait, M.G. (2005). Implementing geoportals: applications of distributed GIS. Computers, Environment and Urban Systems, 29(1), 33-47.

98. Beaumont, P., Longley, P.A., Maguire, D.J. (2005). Geographic information portals - a UK perspective. Computers, Environment and Urban Systems, 29(1), 49-69. 